\title{
Effects of CsSnxPb1-x|3 Quantum Dots as Interfacial Layer on Photovoltaic Performance of Carbon-Based Perovskite Solar Cells
}

\section{Chi Zhang}

Wuhan University of Technology

Zhiyuan He

Wuhan University of Technology

Xuanhui Luo

Wuhan University of Technology

Rangwei Meng

Wuhan University of Technology

Mengwei Chen

Wuhan University of Technology

Haifei Lu

Wuhan University of Technology

yingping yang ( $\nabla$ ypyang@whut.edu.cn )

"Wuhan University of Technology" https://orcid.org/0000-0002-4183-674X

\section{Nano Express}

Keywords: Tin-doped perovskite quantum dots, photovoltaic performance, carbon-based perovskite solar cells

Posted Date: February 16th, 2021

DOI: https://doi.org/10.21203/rs.3.rs-196729/v1

License: (c) (1) This work is licensed under a Creative Commons Attribution 4.0 International License. Read Full License 


\section{Effects of $\mathrm{CsSn}_{x} \mathrm{~Pb}_{1-x} \mathbf{I}_{3}$ quantum dots as interfacial layer on photovoltaic}

\section{2 performance of carbon-based perovskite solar cells}

3 Chi Zhang, Zhiyuan He, Xuanhui Luo, Rangwei Meng, Mengwei Chen, Haifei Lu and

$4 \quad$ Yingping Yang*

5

*correspondence: ypyang@,whut.edu.cn

Department of Physics, School of Science, Wuhan University of Technology, Wuhan 430070, P. R. China

\section{Abstract}

In this work, inorganic tin-doped perovskite quantum dots (PQDs) are incorporated into carbonbased perovskite solar cells (PSCs) to improve their photovoltaic performance. On the one hand, by controlling the content of $\mathrm{Sn}^{2+}$ doping, the energy level of the tin-doped PQDs can be adjusted, to realize optimized band alignment and enhanced separation of photogenerated electron-hole pairs. On the other hand, the incorporation of tin-doped PQDs provided with a relatively high acceptor concentration due to the self-p-type doping effect, is able to reduce the width of the depletion region near the back surface of the perovskite, thereby enhancing the hole extraction. Especially, after the addition of $\mathrm{CsSn}_{0.2} \mathrm{~Pb}_{0.8} \mathrm{I}_{3}$ QDs, improvement of the power conversion efficiency (PCE) from $12.80 \%$ to $14.22 \%$ can be obtained, in comparison to the pristine device. Moreover, the experimental results are analyzed through the simulation of the one-dimensional perovskite/tin-doped PQDs heterojunction.

Keywords: Tin-doped perovskite quantum dots, photovoltaic performance, carbon-based perovskite solar cells 


\section{Introduction}

2 In past few years, perovskite materials have been widely applied in solar cells due to their

3 excellent electrical and optical properties, such as suitable bandgap width, large light absorption

4 coefficient and good defect tolerance [1-6]. Interface engineering, as a strategy to modify the interface characteristics of thin film devices, has become one of the approaches to improve the performance of perovskite solar cells (PSCs) [7,8]. Recently, lead-based halide perovskite quantum dots (PQDs) in the form of $\mathrm{APbX}_{3}\left(\mathrm{~A}=\mathrm{CH}_{3} \mathrm{NH}_{3}^{+}\left(\mathrm{MA}^{+}\right), \mathrm{Cs}^{+} ; \mathrm{X}=\mathrm{Cl}^{-}, \mathrm{Br}^{-}, \mathrm{I}^{-}\right)$are often used as interfacial layers or additives for optimized band alignment thanks to their adjustable band structures [9-15]. The combination of perovskite absorbers and PQDs is regarded as an effective method for enhanced charge extraction and improved PSC properties.

It is worth noting that most of the relevant researches are based on PSCs with holetransporting layers (HTLs). But in recent years, carbon-based HTL-free PSCs with simple preparation processes and low costs have been given much attention [16-18]. Similarly, PQDs can also be used in this PSC structure. However, some other requirements besides band alignment should be taken into consideration. First, the lattice structures of lead-based PQDs are not very stable due to $\mathrm{Pb}^{2+}$ with a large ionic radius reducing the tolerance factor. Therefore, lead-reduced PQDs are promising candidates. Second, because of the lack of HTLs, the hole transport performance is bound to be weakened. Consequently, the added PQDs are required to supply extra free holes, so that photogenerated holes can be smoothly transferred from the perovskite layer to the carbon electrode.

The ion exchange method using metal cations with smaller ionic radii (such as $\mathrm{Cu}^{2+}, \mathrm{Zn}^{2+}$, $\mathrm{Sn}^{2+}, \mathrm{Cd}^{2+}$ ) to partially replace $\mathrm{Pb}^{2+}$ has been proven to improve the lattice stability of PQDs 
$1 \quad$ [19-21]. Among these metal cations, $\mathrm{Sn}^{2+}$ is easily to oxidize to $\mathrm{Sn}^{4+}$, which can introduce self-

2 p-type doping effects to enhance hole transfer [22-24]. Especially, Liu et al. synthesized

$3 \mathrm{CsSn}_{0.6} \mathrm{~Pb}_{0.4} \mathrm{I}_{3}$ QDs featuring a hole mobility of $40.12 \mathrm{~cm}^{2} \mathrm{~V}^{-1} \mathrm{~s}^{-1}$ and good stability in the

4 ambient air [25]. Xu and co-workers incorporated $\mathrm{CsSnBr}_{3-x} \mathrm{I}_{x}$ QDs between the $\mathrm{CsPbBr}_{3}$

5 perovskite and the carbon electrode to promote charge extraction [26]. Very recently, Duan et

6 al. found that $\mathrm{MAPbI}_{3} / \mathrm{CsSnI}_{3}$ heterojunction as the light-harvester in the carbon-based HTL-

7 free PSC could facilitate the hole transfer [27]. Inspired by these above, we propose that tin-

8 doped PQDs with appropriate energy levels and self-p-type doping effects are able to function

9 like HTLs to modify the injection and transport characteristics of holes.

In this work, tin-doped PQDs in the form of $\mathrm{CsSn}_{x} \mathrm{~Pb}_{1-x} \mathrm{I}_{3}$ were incorporated between the $\mathrm{MAPbI}_{3}$ perovskite and the carbon electrode to achieve optimized band alignment and improved hole transfer. An increment in power conversion efficiency (PCE) of $11.09 \%$, from $12.80 \%$ to $14.22 \%$, could be obtained after the addition of $\mathrm{CsSn}_{0.2} \mathrm{~Pb}_{0.8} \mathrm{I}_{3}$ QDs.

\section{Methods}

\section{Materials}

Tin iodide $\left(\mathrm{SnI}_{2} ; 99.99 \%\right)$ was bought from Youxuan technology (China). Cesium carbonate $\left(\mathrm{Cs}_{2} \mathrm{CO}_{3} ; 99 \%\right)$, 1-octadecene (ODE; $\left.>90 \%\right)$, oleic acid $(\mathrm{OA} ; 99 \%)$, oleylamine (OAM; 80\%90\%), methyl acetate (MeOAc; 98\%) and trioctylphosphine (TOP; 90\%) were purchased from Macklin (China). Lead iodide $\left(\mathrm{PbI}_{2} ; 99.99 \%\right)$ and methylammonium iodide (MAI; 99.5\%) were obtained from Xi'an p-OLED (China). Titanium diisopropoxide bis (acetylacetonate; 75\%), 
1 purchased from Sigma-Aldrich (US). The $\mathrm{TiO}_{2}$ paste (30NR-D) and the low-temperature

2 carbon electrode paste were obtained from Shanghai MaterWin New Materials (China).

3

4

5

6

7

\section{Synthesis and purification of tin-doped PQDs}

We adopted a simple mixed-heating procedure to synthesize tin-doped PQDs. Briefly, $\mathrm{Cs}_{2} \mathrm{CO}_{3}$, $\mathrm{SnI}_{2}$ and $\mathrm{PbI}_{2}$ with a specific molar ratio $\left(\mathrm{CsSn}_{0.1} \mathrm{~Pb}_{0.9} \mathrm{I}_{3}\right.$ QDs: $0.037 \mathrm{mmol} \mathrm{Cs}_{2} \mathrm{CO}_{3}, 0.2 \mathrm{mmol}$ $\mathrm{PbI}_{2}, 0.15 \mathrm{mmol} \mathrm{SnI}_{2} ; \mathrm{CsSn}_{0.2} \mathrm{~Pb}_{0.8} \mathrm{I}_{3}$ QDs: $0.037 \mathrm{mmol} \mathrm{Cs}_{2} \mathrm{CO}_{3}, 0.2 \mathrm{mmol} \mathrm{PbI}, 0.2 \mathrm{mmol} \mathrm{SnI}_{2}$; $\mathrm{CsSn}_{0.3} \mathrm{~Pb}_{0.7} \mathrm{I}_{3}$ QDs: $0.037 \mathrm{mmol} \mathrm{Cs}_{2} \mathrm{CO}_{3}, 0.2 \mathrm{mmol} \mathrm{PbI}_{2}, 0.25 \mathrm{mmol} \mathrm{SnI}_{2}$ ) were mixed with 10 $\mathrm{mL}$ of ODE, $0.5 \mathrm{~mL}$ of OA, $0.5 \mathrm{~mL}$ of OAM and $0.5 \mathrm{~mL}$ of TOP in a $50-\mathrm{mL}$ three-neck flask. OA, OAM and TOP were utilized to limit the particle size and to passivate the surface defects of tin-doped PQDs. Then, the mixture was stirred and heated at $100 \square$ for 30 minutes under nitrogen atmosphere to obtain a red solution, including nano-sized and micron-sized tin-doped perovskites. To extract and purify tin-doped PQDs, $10 \mathrm{~mL}$ of MeOAc was added into the red solution, followed by centrifuging at $7000 \mathrm{rpm}$ for 5 minutes. The supernatant was discarded, and the brown black precipitate was dispersed in $5 \mathrm{~mL}$ of hexane. Finally, the brown black solution was centrifuged at $3000 \mathrm{rpm}$ for 5 minutes, and the red supernatant contained only the tin-doped PQDs.

\section{Device fabrication}

Fluorine-doped $\mathrm{SnO}_{2}$ (FTO) glasses were washed with water, acetone, isopropanol and ethanol in sequence for 30 minutes each in an ultrasonic cleaner. After that, the FTO glasses were treated by ultraviolet (UV) for 20 minutes to remove residual organic solvents. The compact $\mathrm{TiO}_{2}$ (c- 
$\left.1 \quad \mathrm{TiO}_{2}\right)$ layer was fabricated on the FTO layer by spin-coating a solution of acetylacetonate $(0.1$

$2 \mathrm{~mL})$ diluted in ethanol $(1.9 \mathrm{~mL})$ with the speed of $4000 \mathrm{rpm}$ for $30 \mathrm{~s}$. Then the glasses were 3 annealed at $150 \square$ for 5 minutes and at $500 \square$ for 30 minutes. Subsequently, the mesoporous $\mathrm{TiO}_{2}\left(\mathrm{~m}-\mathrm{TiO}_{2}\right)$ layer was obtained by spin-coating a solution of $\mathrm{TiO}_{2}$ paste diluted in ethanol onto the $\mathrm{c}-\mathrm{TiO}_{2}$ layer at $3500 \mathrm{rpm}$ for $20 \mathrm{~s}$, and annealed at $500 \square$ for 30 minutes. The annealing process at $500 \square$ is to obtain $\mathrm{TiO}_{2}$ layers with improved electron transport performance. Next, to prepare the $\mathrm{MAPbI}_{3}$ precursor solution, $\mathrm{PbI}_{2}(0.5 \mathrm{mmol})$ and $\mathrm{MAI}(0.5 \mathrm{mmol})$ were mixed with DMF (300 mg) and DMSO (39 mg). Afterwards, the $\mathrm{MAPbI}_{3}$ layer was fabricated by spincoating the $\mathrm{MAPbI}_{3}$ precursor solution $(35 \mu \mathrm{L})$ onto the $\mathrm{m}-\mathrm{TiO}_{2}$ layer, with the speed of 1000 rpm for $10 \mathrm{~s}$ and $4000 \mathrm{rpm}$ for $20 \mathrm{~s}$, followed by heating at $100 \square$ for 10 minutes. After that, tin-doped PQDs dispersed in toluene $\left(10 \mathrm{mg} \mathrm{mL}^{-1}\right)$ were spin-coated onto the perovskite layer at $4000 \mathrm{rpm}$ for $30 \mathrm{~s}$ and annealed at $90 \square$ for 5 minutes to remove the residual toluene. Finally, the carbon electrode paste was screen-printed on the device and annealed at $100 \square$ for 10 minutes.

\section{Characterization}

Transmission electron microscope (TEM) images, selected area electron diffraction (SAED) views and energy dispersive X-ray spectroscopy (EDS) analyses of tin-doped PQDs were obtained by a field emission high-resolution transmission electron microscope (JEM-2100F, JEOL, Japan) at an accelerating voltage of $200 \mathrm{kV}$. The valence band (VB) edges of different materials were acquired from an X-ray photoelectron spectrometer (ESCALAB 250Xi, Thermo

Fisher Scientific, US). Absorption and steady-state photoluminescence (PL) characteristics 
1 were collected via an UV-visible spectrophotometer (UV-3600, Shimadzu, Japan) and a

2 fluorescence spectrometer (RF-6000, Shimadzu, Japan), respectively. The cross-section image

3 of the PSC and the surface morphologies of perovskite films were obtained by a scanning

4 electron microscope (Zeiss Ultra Plus, Zeiss, Germany). Curves of photocurrent density versus

5 on voltage $(J-V)$ were measured by a sourcemeter (2400, Keithley, US) with a sunlight simulator

6 (Oriel Sol3A, Newport, US), under AM 1.5G simulated illumination $\left(100 \mathrm{~mW} \mathrm{~cm}{ }^{-2}\right)$.

7 Monochromatic incident photon-to-electron conversion efficiency (IPCE) spectra and

8 electrochemical impedance spectroscopies (EIS) were obtained from an electrochemical

9 workstation (Zahner, Kronach, Germany). Finally, X-ray diffraction (XRD) patterns of

10 perovskite films were acquired from an X-ray diffractometer (Empyrean, PANalytical,

11 Netherlands).

\section{Results and Discussion}

Three kinds of tin-doped PQDs were studied in this work, including $\mathrm{CsSn}_{0.1} \mathrm{~Pb}_{0.9} \mathrm{I}_{3}$ QDs,

$\mathrm{CsSn}_{0.2} \mathrm{~Pb}_{0.8} \mathrm{I}_{3}$ QDs and $\mathrm{CsSn}_{0.3} \mathrm{~Pb}_{0.7} \mathrm{I}_{3}$ QDs. The actual atomic ratio of $\mathrm{Sn}$ in these PQDs were estimated to be $13.03 \%, 22.12 \%$ and $32.57 \%$, respectively (shown in Fig. S1 and Table S1-S3). As shown in Fig. 1, blue-shifts of the steady-state PL peak $(673 \mathrm{~nm}, 669 \mathrm{~nm}$ and $656 \mathrm{~nm}$ in turn) and the edge of Tauc plot $(1.79 \mathrm{eV}, 1.80 \mathrm{eV}$ and $1.81 \mathrm{eV}$ in turn) were observed with the increase of Sn doping. The bandgap is known to increase with the decrease of the unit cell volume [19]. Therefore, more $\mathrm{Sn}^{2+}$ substitution would further intensify the lattice contraction, which led to the increased bandgap width, consistent with the reported research [28]. 

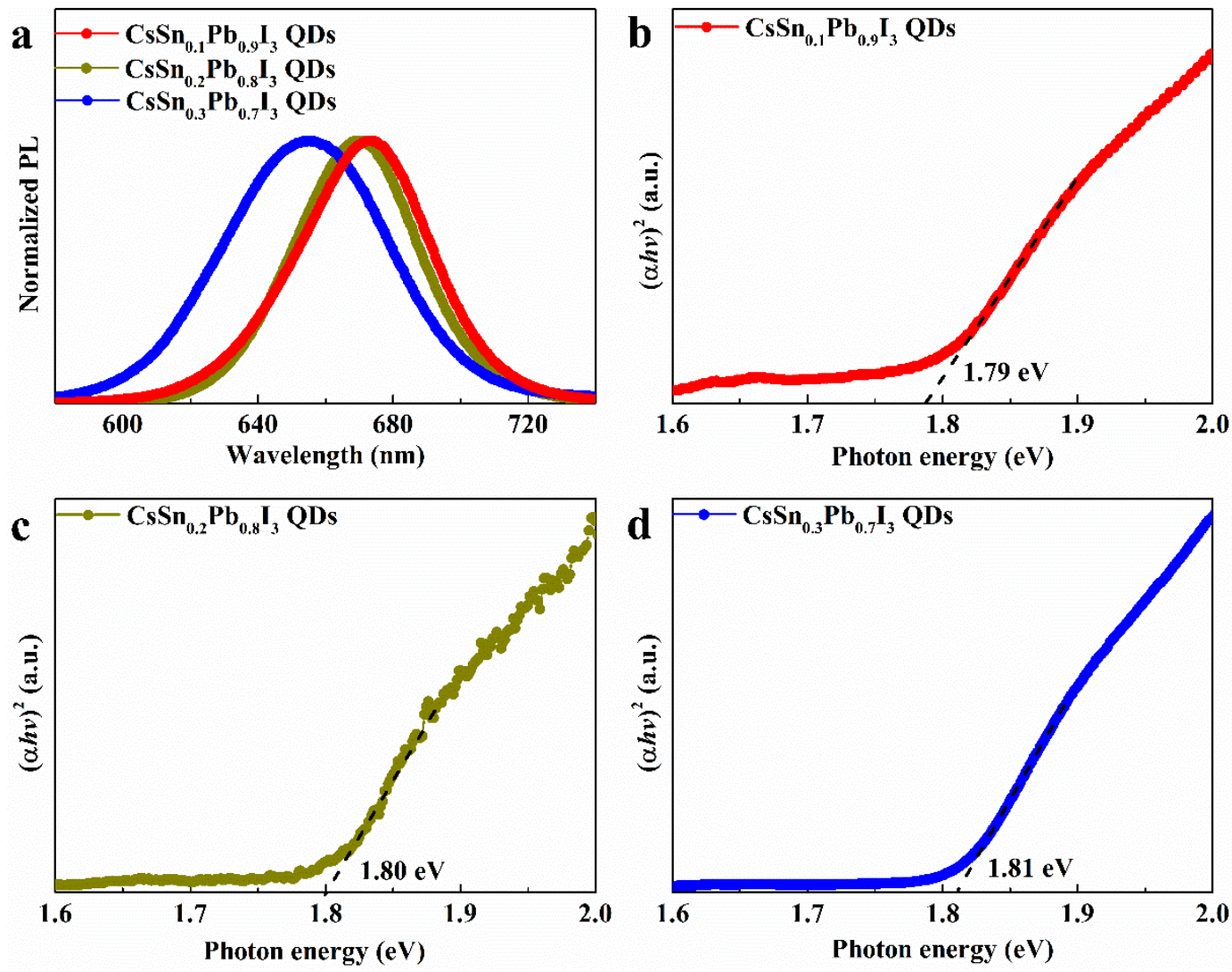

Fig. 1 a Normalized PL spectra and b-d Tauc plots of different tin-doped PQDs

The TEM images of these tin-doped PQDs are exhibited in Fig. 2a-c. These tin-doped PQDs were all square, consistent with the theoretical lattice structure of cubic phase. Besides,

6 all these PQDs showed an average size of about $15 \mathrm{~nm}$ with good homogeneity. The size of the

7 three kinds of quantum dots was not much different. That was because the size of PQDs was mainly determined by the reaction temperature, and the synthesis temperature of these three kinds of PQDs was kept at $100^{\circ} \mathrm{C}$. Besides, corresponding SAED measurements are shown in Fig. 2d-f. By comparing the interplanar spacing values of different diffraction rings with

11 corresponding standard values $\left(\mathrm{CsPbI}_{3}\right.$ in cubic phase, ICSD, 181288), some crystal planes including (100), (110), (200) and (220) could be identified, which also indicated that these tindoped PQDs were mostly composed of cubic nanocrystals (NCs) [20]. Moreover, enlarged 
1 TEM images shown in Fig. 2g-i are utilized to further study the crystal plane characteristics.

2 The interplanar distances of (200) plane of these tin-doped PQDs were determined to be 0.308

$3 \mathrm{~nm}, 0.303 \mathrm{~nm}$ and $0.296 \mathrm{~nm}$ in turn, which could demonstrate that increasing substitution of

$4 \mathrm{~Pb}^{2+}$ by $\mathrm{Sn}^{2+}$ further led to the lattice shrinkage, in accordance with their optical characteristics

5 mentioned above.

$\mathbf{a}$

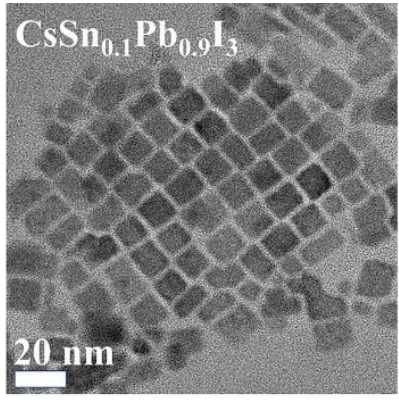

d

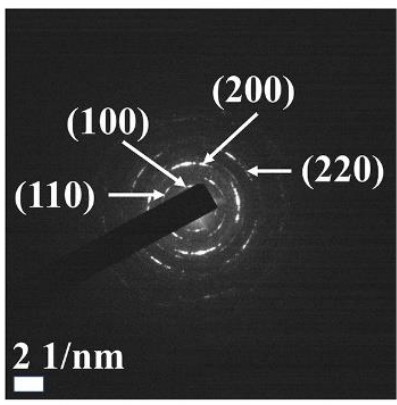

g

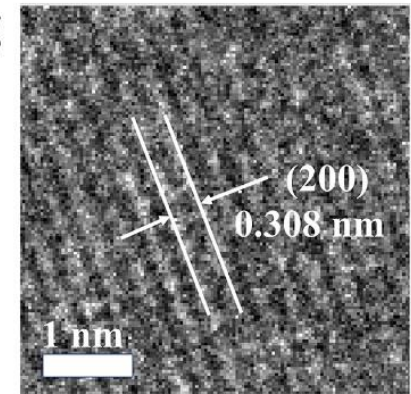

b

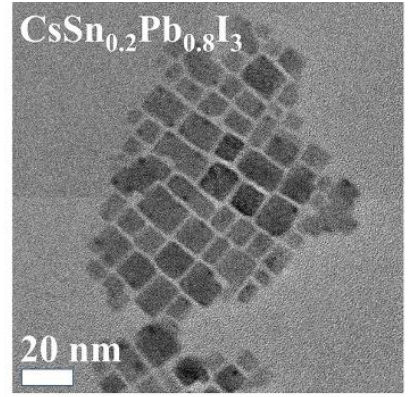

e

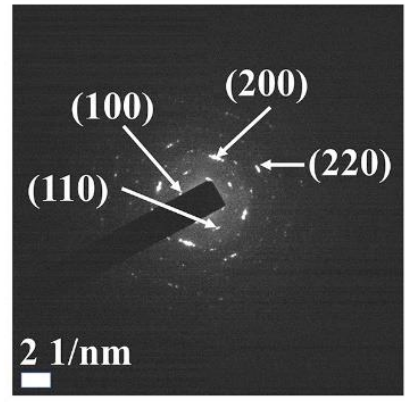

h

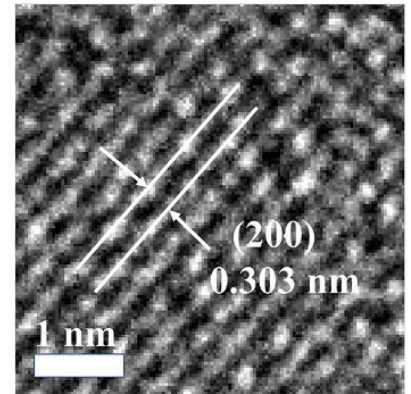

c

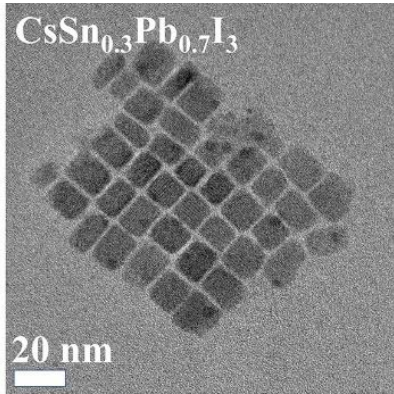

f
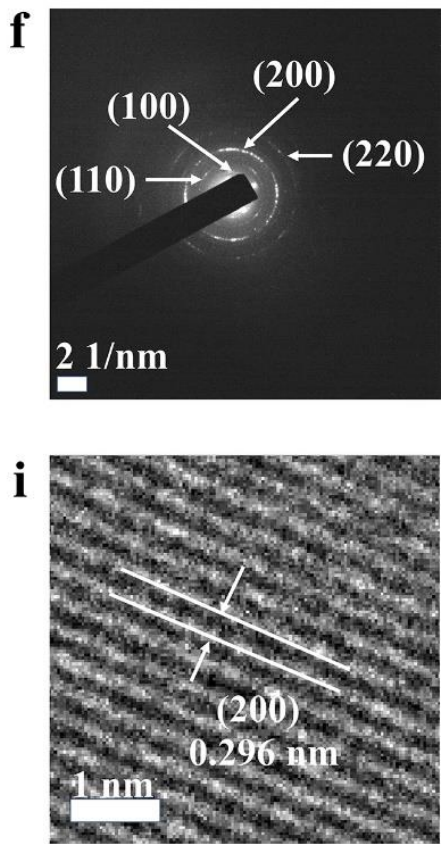

To further study the lattice structures of these tin-doped PQDs, we performed XRD measurements, shown in Fig. 3. According to the standard $\mathrm{XRD}$ data of $\mathrm{CsPbI}_{3}$ in orthorhombic 
1 and cubic phase [20, 29], the diffraction peaks of these tin-doped PQDs associated with

2 orthorhombic and cubic phase were marked with "*”" and "\#”, respectively. As the amount of

3 Sn doping in PQDs increased, the diffraction angle corresponding to (200) plane slightly

4 increased, showing that the interplanar distance of (200) plane was reduced, in line with the

5 analysis above. Meanwhile, the intensities of orthorhombic phase diffraction peaks also showed

6 increasing trends, which indicated that the phase transition process in the PQDs increased. That

7 was because the increase in the amount of Sn doping would intensify the oxidation reaction of

8 the PQDs in the air, resulting in more $\mathrm{Sn}$ vacancies, which may make $\mathrm{Pb}$ refill these vacancies

9 to form an unstable perovskite structure.

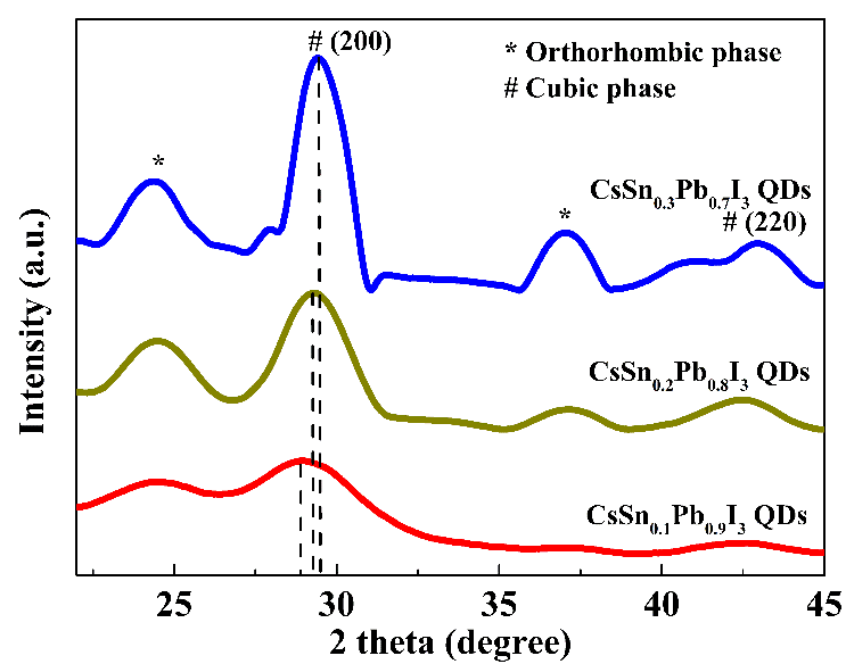

Fig. 3 XRD patterns of different tin-doped PQDs

Optimized band alignment is crucial for enhancing the extraction of photogenerated carriers and suppressing charge recombination [30-33]. Fig. 4 shows the band structures of various materials including $\mathrm{FTO}, \mathrm{TiO}_{2}, \mathrm{MAPbI}_{3}, \mathrm{CsSn}_{0.1} \mathrm{~Pb}_{0.9} \mathrm{I}_{3}$ QDs, $\mathrm{CsSn}_{0.2} \mathrm{~Pb}_{0.8} \mathrm{I}_{3}$ QDs, $\mathrm{CsSn}_{0.3} \mathrm{~Pb}_{0.7} \mathrm{I}_{3}$ QDs and carbon. Corresponding UPS and Tauc plots are shown in Fig. S2. It is clear that the valence band (VB) edge of $\mathrm{CsSn}_{0.1} \mathrm{~Pb}_{0.9} \mathrm{I}_{3}$ QDs $(-5.53 \mathrm{eV})$ and $\mathrm{CsSn}_{0.2} \mathrm{~Pb}_{0.8} \mathrm{I}_{3}$ QDs 
$1(-5.50 \mathrm{eV})$ was higher than that of $\mathrm{MAPbI}_{3}(-5.54 \mathrm{eV})$, satisfying the band alignment

2 requirement. It was able to eliminate the large Schottky barrier formed by the $\mathrm{MAPbI}_{3} /$ carbon

3 junction, thus enhancing the hole extraction ability (discussed later) [31]. Furthermore, the

4 higher conduction band (CB) edges of these tin-doped PQDs were expected to hinder the flow

5 of electrons from $\mathrm{MAPbI}_{3}$ to the carbon electrode. However, the $\mathrm{VB}$ edge of $\mathrm{CsSn}_{0.3} \mathrm{~Pb}_{0.7} \mathrm{I}_{3} \mathrm{QDs}$

6 was lower than that of $\mathrm{MAPbI}_{3}$, which would block the hole injection, leading to more charge

7 recombination at the interface between $\mathrm{MAPbI}_{3}$ and the PQDs.

\section{Energy (eV)}

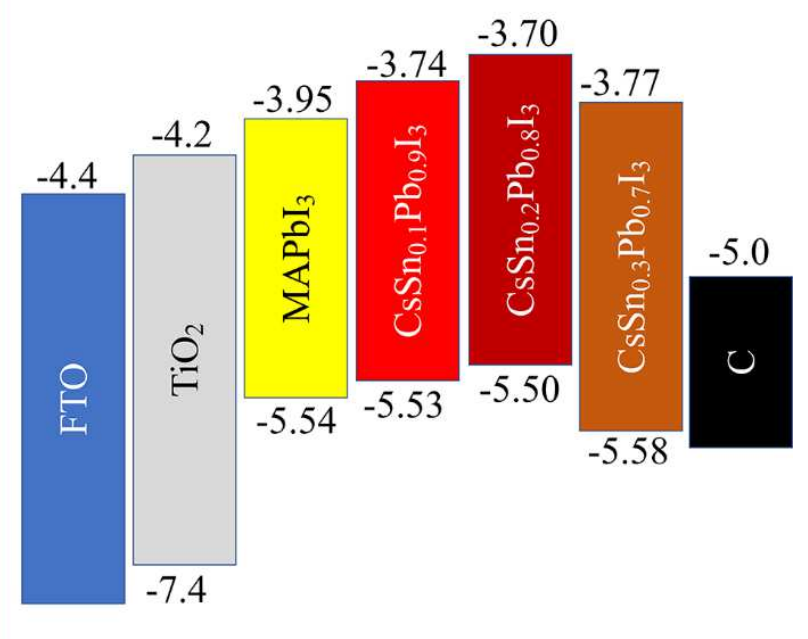

Fig. 4 Band structures of different materials in PSCs

Moreover, the VB edge originates from the interactions between $\mathrm{Pb}$ and I orbitals, which is also determined by the $\mathrm{Sn}$ doping amount. On the one hand, the substitution of $\mathrm{Pb}^{2+}$ by $\mathrm{Sn}^{2+}$ will shrink the lattice structure, leading to shorter $\mathrm{Pb}$-I bonds and stronger interactions between $\mathrm{Pb}$ and I orbitals, so that the VB tends to shift to a higher energy [19]. On the other hand, more lattice distortions (transformation from cubic NCs to orthorhombic NCs) will be introduced into the PQDs with the excessive $\mathrm{Sn}^{2+}$ substitution, resulting in expanded volume of $\left[\mathrm{PbI}_{6}\right]$ 
octahedra and weaker $\mathrm{Pb}-\mathrm{I}$ interactions, thus moving the VB to a lower energy position [21]. As a result, a reasonable Sn doping content is the key to obtaining an appropriate band structure. Unlike ordinary lead-based PQDs, tin-doped PQDs will partially undergo oxidation in air due to the presence of $\mathrm{Sn}^{2+}$, described by

$$
2 \mathrm{CsSn}_{x} \mathrm{~Pb}_{1-x} \mathrm{I}_{3}+x \mathrm{O}_{2} \rightarrow x \mathrm{Cs}_{2} \mathrm{SnI}_{6}+(2-2 x) \mathrm{CsPbI}_{3}+x \mathrm{SnO}_{2}
$$

$\mathrm{CsSn}_{x} \mathrm{~Pb}_{1-x} \mathrm{I}_{3}$ can be assumed to be the combination of $\mathrm{CsSnI}_{3}$ and $\mathrm{CsPbI}_{3}$ with a certain molar ratio. Among the compounds, only $\mathrm{CsSnI}_{3}$ participates in the oxidation reaction. And then, this process can be simplified to

$$
2 \mathrm{CsSnI}_{3}+\mathrm{O}_{2} \rightarrow \mathrm{Cs}_{2} \mathrm{SnI}_{6}+\mathrm{SnO}_{2}
$$

In reaction (2), the transformation from $\mathrm{CsSnI}_{3}$ to $\mathrm{Cs}_{2} \mathrm{SnI}_{6}$ is regarded as breaking the connections between $\left[\mathrm{SnI}_{6}\right]$ octahedra. The reason is that $\mathrm{CsSnI}_{3}$ is formed by corner sharing [SnI 6 ] octahedra while $\mathrm{Cs}_{2} \mathrm{SnI}_{6}$ is made up of isolated [SnI 6 ] octahedra [22]. Therefore, this half of Sn atoms do not leave the perovskite lattice. However, the other half of Sn atoms are oxidized to $\mathrm{SnO}_{2}$, leaving a lot of $\mathrm{Sn}$ vacancies in the lattice, which will accept electrons (or supply holes) and act as p-type dopants. It can be described by the equation (3) below

$$
\mathrm{Sn}^{2+}+\mathrm{O}_{2} \rightarrow \mathrm{SnO}_{2}+2 \mathrm{~h}^{+}
$$

That is the reason for the self-p-type doping effects of tin-doped PQDs. Accordingly, under the premise that the lattice structure of tin-doped PQDs can be stabilized, the more $\mathrm{Sn}^{2+}$ doping, the higher acceptor concentration of the PQDs.

The cross-sectional image of the PSC is shown in Fig. 5a. The widths of FTO layer and $\mathrm{TiO}_{2} / \mathrm{MAPbI}_{3}$ composite layer were about $400 \mathrm{~nm}$ and $800 \mathrm{~nm}$, respectively. Because of the low concentration of the PQD solution $\left(10 \mathrm{mg} \mathrm{mL}^{-1}\right)$, it was hard to observe a PQD layer that 
1 could be distinguished from the underlying $\mathrm{MAPbI}_{3}$ film. Besides, as shown in Fig. 5b-f, there

2 were many small-sized white $\mathrm{PbI}_{2}$ particles on the original perovskite film, which was caused

3 by the partial decomposition of the perovskite in the air. After adding tin-doped PQDs, the

4 number of white particles decreased, and the perovskite films exhibited slightly better grain

5 uniformity and compactness than the control sample. However, the morphology difference

6 between the various perovskite films was still not obvious. In order to further distinguish their

7 surface characteristics, we performed grazing incidence XRD (GIXRD) patterns of perovskite

8 films with different tin-doped PQDs, exhibited in Fig. 6. The diffraction peak at about $12.7^{\circ}$ is

9 associated with $\mathrm{PbI}_{2}$ [34]. After the modification of tin-doped PQDs, the intensity of $\mathrm{PbI}_{2}-$ peak

10 was weakened while the intensity of the diffraction peak corresponding to (110) plane of the

11 perovskite increased, indicating that the decomposition process of the perovskite film was

12 suppressed.

a
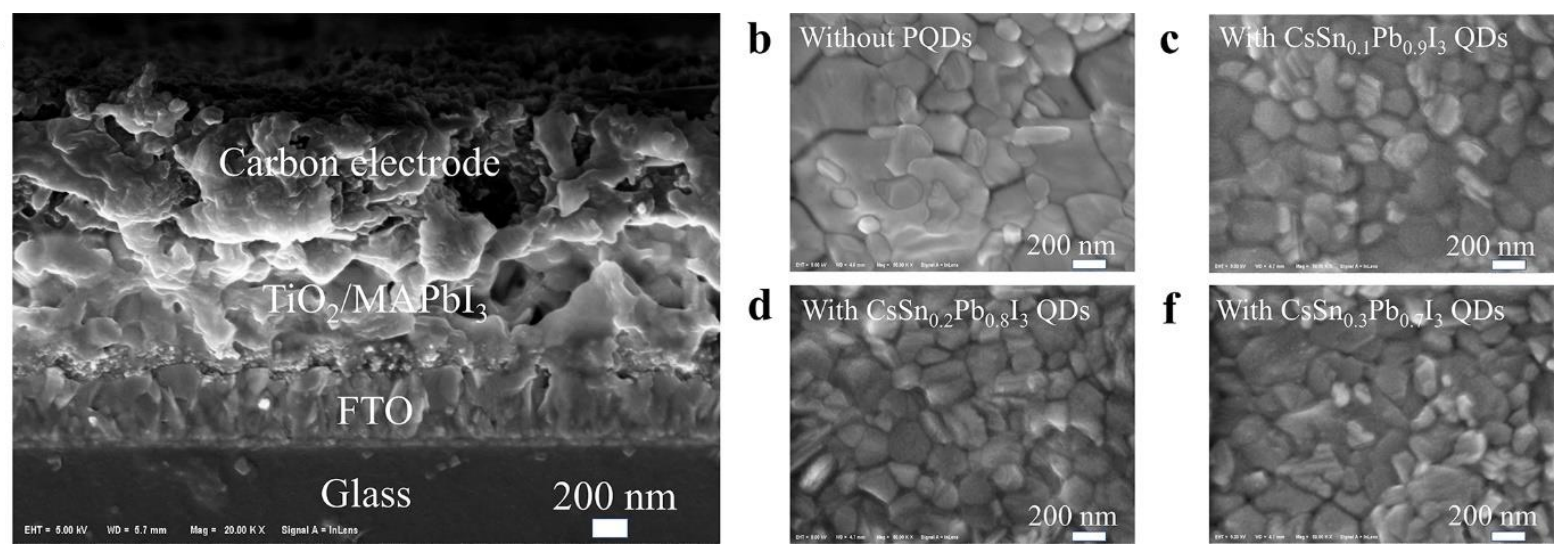

f

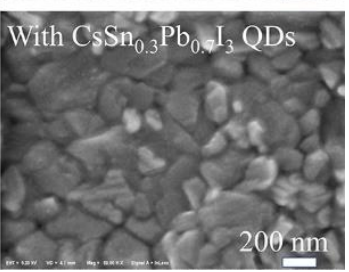

Fig. 5 a Cross-sectional image of the PSC. b-f Perovskite films without and with tin-doped

PQDs. 


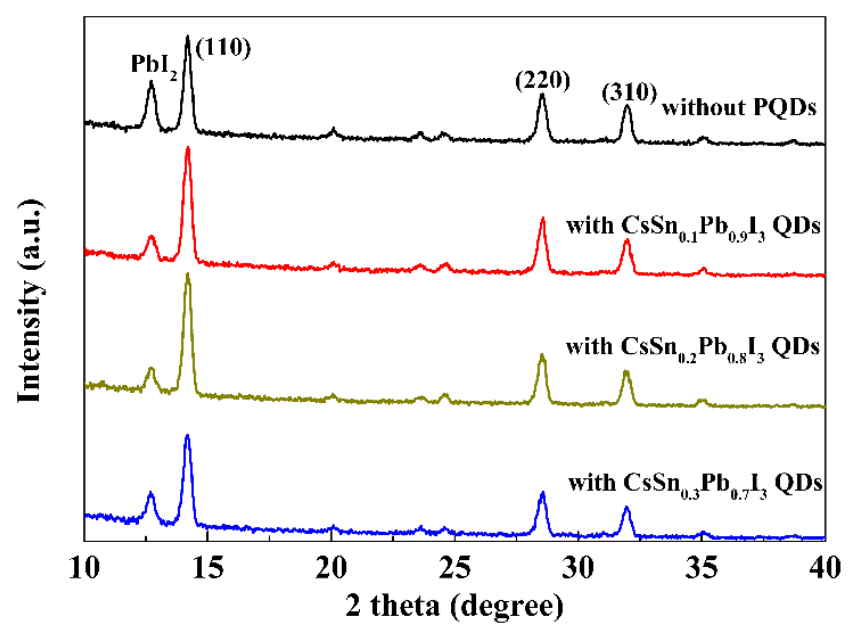

Fig. 6 GIXRD patterns of different perovskite films

The curves of photocurrent density versus on voltage $(J-V)$ of different PSCs are displayed in Fig. $7 \mathrm{a}$, and photovoltaic parameters including short circuit current density $\left(J_{\mathrm{sc}}\right)$, open circuit voltage $\left(V_{\mathrm{oc}}\right)$, fill factor $(\mathrm{FF})$ and PCE are shown in Table 1 . The values of $J_{\mathrm{sc}}, V_{\mathrm{oc}}, \mathrm{FF}$, and PCE of the PSC without modification by tin-doped PQDs were $22.69 \mathrm{~mA} \mathrm{~cm}^{-2}, 0.99 \mathrm{~V}, 56.78 \%$ and $12.80 \%$, respectively. For the $\mathrm{CsSn}_{0.1} \mathrm{~Pb}_{0.9} \mathrm{I}_{3}$ QDs-added PSC, various parameters were improved. However, the improvement was not optimal, which might ascribe to the relatively low Sn doping of the PQDs. In contrast, with the incorporation of $\mathrm{CsSn}_{0.2} \mathrm{~Pb}_{0.8} \mathrm{I}_{3}$ QDs, a $J_{\mathrm{sc}}$ of $23.30 \mathrm{~mA} \mathrm{~cm}^{-2}$, a $V_{\text {oc }}$ of $1.05 \mathrm{~V}$, a FF of $57.90 \%$ and a PCE of $14.22 \%$ could be obtained. The significant increase in each parameter indicated the reduction of non-radiative recombination and the effective extraction of photogenerated holes. Besides, as shown in Fig. S3, PCE values for $90 \%$ of $\mathrm{CsSn}_{0.2} \mathrm{~Pb}_{0.8} \mathrm{I}_{3}$ QDs-added PSCs surpassed 13\%, showing good repeatability. But for the PSC modified by $\mathrm{CsSn}_{0.3} \mathrm{~Pb}_{0.7} \mathrm{I}_{3}$ QDs, the values of $J_{\text {sc }}$ and FF seriously dropped to 16.82 $\mathrm{mA} \mathrm{cm}{ }^{-2}$ and $47.40 \%$, respectively. The lower VB edge of the PQDs would hinder the hole transfer from the $\mathrm{MAPbI}_{3}$ film to the carbon electrode. Furthermore, when the $\mathrm{Sn}$ content of 
1 PQDs was too high, more Sn vacancies would be introduced, which would not only provide

2 more free holes, but also result in more phase transformation products with large bandgap

3 widths [29, 35-37], and thus seriously impeding the transport process of photogenerated carriers.

As described in Fig. 7b, the IPCE spectra in a wavelength range from $350 \mathrm{~nm}$ to $800 \mathrm{~nm}$ increased in the order of $\mathrm{CsSn}_{0.3} \mathrm{~Pb}_{0.7} \mathrm{I}_{3}$ QDs-added device $<$ control device $<\mathrm{CsSn}_{0.1} \mathrm{~Pb}_{0.9} \mathrm{I}_{3}$ QDs-added device $<\mathrm{CsSn}_{0.2} \mathrm{~Pb}_{0.8} \mathrm{I}_{3}$ QDs-added device, in agreement with the corresponding trend of $J_{\text {sc }}$ acquired from the $J-V$ curves. It is clear that the difference of these IPCE curves was mainly reflected in the wavelength range from $550 \mathrm{~nm}$ to $800 \mathrm{~nm}$. Tin-doped PQDs added onto the perovskite film would significantly affect the built-in electric field near the back surface of the perovskite (analyzed in detail later). At the same time, these long-wavelength lights were mainly absorbed by the perovskite near the back surface due to their low energy. After these photons were converted into carriers, their transport properties would be more easily changed by the above-mentioned built-in electric field than those photogenerated carriers of short-wavelength lights.

In addition, EIS measurements, in a frequency range from $4 \mathrm{MHz}$ to $0.2 \mathrm{MHz}$ at a bias of $0.8 \mathrm{~V}$ under simulated AM $1.5 \mathrm{G}$ radiation, were performed to analyze the charge transport resistance $\left(R_{\mathrm{CT}}\right)$ and the barrier capacitance $\left(C_{\mathrm{T}}\right)$ near the carbon electrode, described in Fig. 7c. Corresponding EIS parameters are also shown in Table 1. With the addition of $\mathrm{CsSn}_{0.2} \mathrm{~Pb}_{0.8} \mathrm{I}_{3}$ QDs, the $R_{\mathrm{CT}}$ value was reduced, which meant the promoted hole extraction and the decreased energy loss on the back surface of $\mathrm{MAPbI}_{3}$. Furthermore, compared with the pristine and the $\mathrm{CsSn}_{0.1} \mathrm{~Pb}_{0.9} \mathrm{I}_{3}$ QDs-added PSCs, the value of $C_{\mathrm{T}}$ increased, so that a shorter depletion width near the back surface of $\mathrm{MAPbI}_{3}\left(W_{\mathrm{D}}\right)$ could be deduced based on the following formulas, 
suggesting facilitated hole transfer.

$$
\begin{gathered}
C_{\mathrm{T}}=\frac{C_{1} C_{2}}{C_{1}+C_{2}} \\
C_{1}=\frac{\varepsilon_{\mathrm{MAPb}_{3}} A}{W_{\mathrm{D}}} \\
C_{2}=\frac{\varepsilon_{\mathrm{QD}} A}{d_{\mathrm{QD}}}
\end{gathered}
$$

where $A$ is the active area and $d_{\mathrm{QD}}$ is the width of the PQD layer. It is worth noting that the contact between $\mathrm{MAPbI}_{3}$ and the PQDs would form a hole depletion region in $\mathrm{MAPbI}_{3}$. Then, the contact between the PQDs and the carbon electrode would generate a Schottky barrier, which led to a hole depletion region in the PQD layer. Both the depletion regions in $\mathrm{MAPbI}_{3}$ and the PQDs contributed to the barrier capacitance value. For the PSC in the presence of $\mathrm{CsSn}_{0.3} \mathrm{~Pb}_{0.7} \mathrm{I}_{3} \mathrm{QDs}$, the lower VB edge of the PQDs allowed more holes to migrate from the PQD layer to the $\mathrm{MAPbI}_{3}$ film. These holes gradually moved away from the $\mathrm{MAPbI}_{3} / \mathrm{PQDs}$ interface under the isotype heterojunction electric field, thereby increasing the $W_{\mathrm{D}}$. This might be the reason why the $C_{\mathrm{T}}$ value of $\mathrm{CsSn}_{0.3} \mathrm{~Pb}_{0.7} \mathrm{I}_{3}$ QDs-added device was low.

To get insight on the carrier transfer process, the steady-state PL spectra for the pure $\mathrm{MAPbI}_{3}$ film and $\mathrm{MAPbI}_{3}$ films covered by different tin-doped PQDs were measured. As shown in Fig. 7d, the PL peak intensity at about $775 \mathrm{~nm}$ was obviously decreased after the incorporation of $\mathrm{CsSn}_{0.1} \mathrm{~Pb}_{0.9} \mathrm{I}_{3} \mathrm{QDs}$ or $\mathrm{CsSn}_{0.2} \mathrm{~Pb}_{0.8} \mathrm{I}_{3} \mathrm{QDs}$. There were two explanations for the weakening of PL intensity: first, the PQDs cause additional non-radiative pathways to capture photogenerated carriers; second, the higher VB edges of PQDs allow more photogenerated holes to migrate to the PQD layer, thus the number of carriers participating in direct recombination is reduced. However, after adding $\mathrm{CsSn}_{0.3} \mathrm{~Pb}_{0.7} \mathrm{I}_{3}$ QDs with more orthorhombic 
1 by-products and lower VB edge, the PL intensity increased, which showed that more carriers

2 were limited in the perovskite film without being trapped by defects. Therefore, the PL quench

3 of the perovskite film with $\mathrm{CsSn}_{0.1} \mathrm{~Pb}_{0.9} \mathrm{I}_{3}$ QDs or $\mathrm{CsSn}_{0.2} \mathrm{~Pb}_{0.8} \mathrm{I}_{3}$ QDs was caused by the

4 optimized band alignment promoting the hole extraction, instead of interfacial trap-assisted

5 recombination. (1)
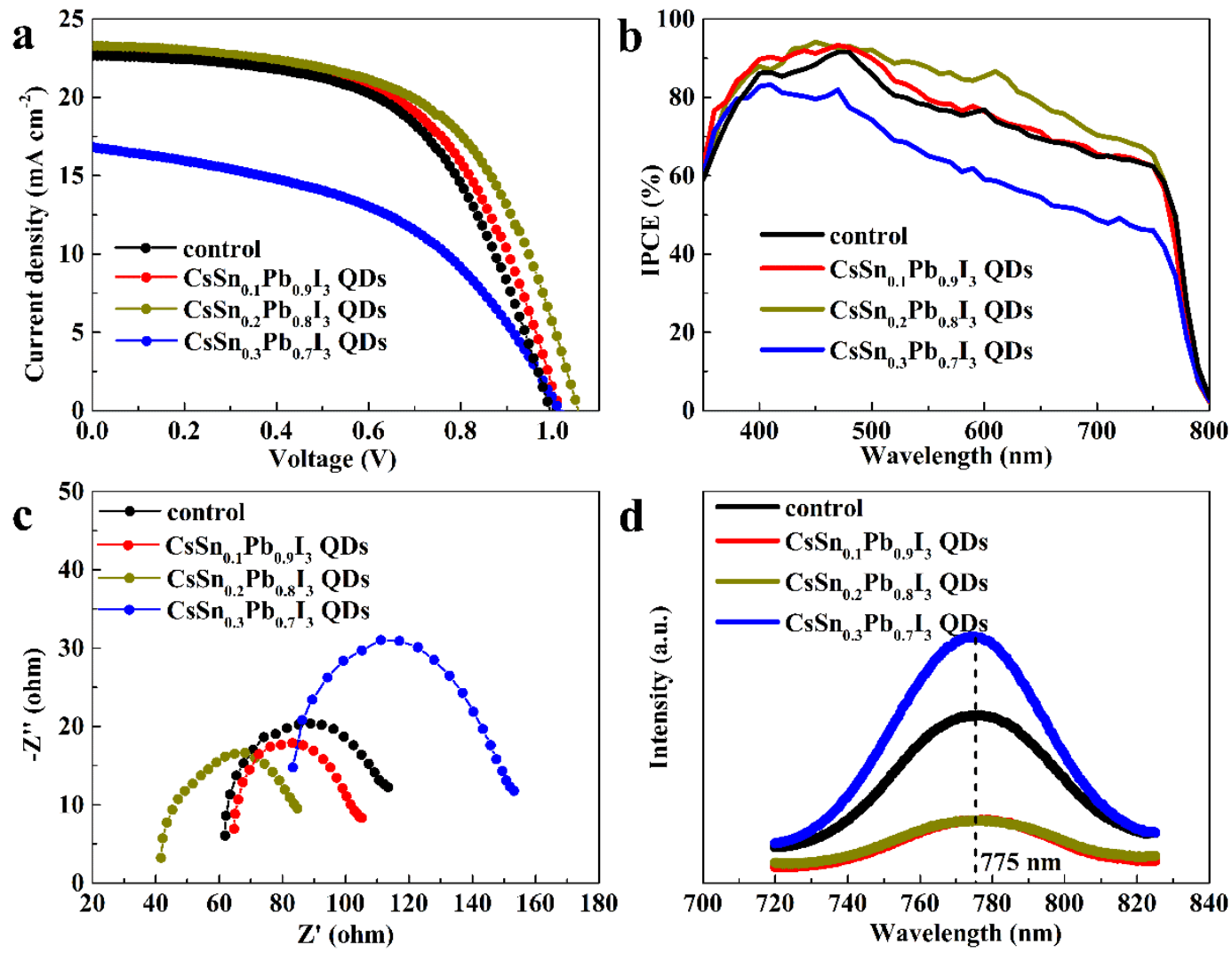

Fig. 7 a $J$ - $V$ curves, b IPCE spectra and $\mathbf{c}$ EIS measurements of different PSCs. d PL spectra of perovskite films with and without tin-doped PQDs.

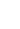


1 Table 1 Photovoltaic parameters of different PSCs

\begin{tabular}{ccccccc}
\hline Device & $V_{\text {oc }}(\mathrm{V})$ & $J_{\text {sc }}\left(\mathrm{mA} \mathrm{cm}^{-2}\right)$ & FF (\%) & PCE $(\%)$ & $R_{\mathrm{CT}}(\Omega)$ & $C_{\mathrm{T}}(\mathrm{nF})$ \\
\hline Control & 0.99 & 22.69 & 56.78 & 12.80 & 56.5 & 35.5 \\
With CsSn $0.1 \mathrm{~Pb}_{0.9} \mathrm{I}_{3}$ QDs & 1.01 & 22.85 & 57.81 & 13.38 & 47.0 & 32.9 \\
With $\mathrm{CsSn}_{0.2} \mathrm{~Pb}_{0.8} \mathrm{I}_{3}$ QDs & 1.05 & 23.30 & 57.90 & 14.22 & 43.0 & 44.7 \\
With $\mathrm{CsSn}_{0.3} \mathrm{~Pb}_{0.7} \mathrm{I}_{3}$ QDs & 1.01 & 16.82 & 47.40 & 8.07 & 81.4 & 16.3 \\
\hline
\end{tabular}

In order to further understand the effects of tin-doped PQDs on the hole transport in

$4 \mathrm{MAPbI}_{3}$ films, a one-dimensional $\mathrm{MAPbI}_{3} /$ tin-doped PQDs heterojunction model was

5 constructed, shown in Fig. 8a. To simplify the analysis, this structure was regarded as a mutant

6 isotype heterojunction, and $\mathrm{MAPbI}_{3}$ and tin-doped PQDs were determined to be p-type

7 semiconductors. Theoretically, $\mathrm{MAPbI}_{3}$ is a kind of intrinsic semiconductor with low doping

8 amount, but in the carbon-based perovskite PSCs with no HTLs, the perovskite layer needs to

9 undergo p-type doping treatment. A small amount of DMSO were added in the precursor of

10 perovskite to form a complex with $\mathrm{PbI}_{2}$, so that there was a small amount of $\mathrm{Pb}$ vacancy in the

11 perovskite, which made the perovskite become a p-type semiconductor. Moreover, Laban and

12 Etgar utilized Mott-Schottky analysis to find that the acceptor concentration of $\mathrm{MAPbI}_{3}$ was

$132.14 \times 10^{17} \mathrm{~cm}^{-3}$, belonging to the doping level of p-type semiconductor [38]. The contact of two

14 semiconductors with different Fermi levels would form an electric field from the one with a

15 high Fermi level to the another with a low Fermi level. Consequently, the p-p isotype

16 heterojunction energy-band diagram under the equilibrium condition could be obtained, shown

17 in Fig. 8b. According to the Poisson's equation, the field continuity condition and the depletion 
1 approximation [39], barrier distributions of the isotype heterojunction were expressed by the

2 following equations

3

4

5

6

$$
\begin{aligned}
& \exp \left(\frac{q V_{\mathrm{D}_{-} \mathrm{QD}}}{k_{\mathrm{B}} T}\right)-\frac{q V_{\mathrm{D}_{-} \mathrm{QD}}}{k_{\mathrm{B}} T}-1=\frac{\varepsilon_{\mathrm{MAPb}_{3}} N_{\mathrm{A}_{-} \mathrm{MAPb}_{3}}}{\varepsilon_{\mathrm{QD}} N_{\mathrm{A}_{-} \mathrm{QD}}} \frac{q V_{\mathrm{D}_{-} \mathrm{MAPb}_{3}}}{k_{\mathrm{B}} T} \\
& q V_{\mathrm{D} \_M A P b_{3}}+q V_{\mathrm{D} \_\mathrm{QD}}=E_{\mathrm{Fermi} \_\mathrm{QD}}-E_{\mathrm{Fermi}_{2} \mathrm{MAPbI}_{3}} \\
& E_{\mathrm{Fermi}}^{\mathrm{p}}=\frac{1}{2} E_{\mathrm{CB}}+E_{\mathrm{VB}}-\frac{1}{2} k_{\mathrm{B}} T \ln \left(\frac{N_{\mathrm{C}}}{N_{\mathrm{V}}}\right)-k_{\mathrm{B}} T \ln \left(\frac{N_{\mathrm{a}}}{n_{\mathrm{i}}}\right) \\
& W_{\mathrm{D}}=\sqrt{\frac{2 \varepsilon_{\mathrm{MAPbI}_{3}} V_{\mathrm{D} \_\mathrm{MAPH}_{3}}}{q N_{\mathrm{A} \_\mathrm{MAPb} I_{3}}}}
\end{aligned}
$$

where $q$ is the elementary charge, $\varepsilon_{\mathrm{QD}}$ and $N_{\mathrm{A}} \mathrm{QD}$ are the dielectric coefficient and the acceptor concentration for tin-doped PQDs, respectively. $V_{\mathrm{D} \_\mathrm{MAPbI3}}$ and $V_{\mathrm{D} \_\mathrm{QD}}$ are the potential difference in $\mathrm{MAPbI}_{3}$ and tin-doped PQDs in turn. $E_{\text {Fermi_MAPbiz }}$ and $E_{\text {Fermi_QD }}$ stand for the Fermi levels of $\mathrm{MAPbI}_{3}$ and tin-doped PQDs, respectively. $k_{\mathrm{B}}$ is the Boltzmann constant and $T$ is the room temperature. $N_{\mathrm{C}}$ and $N_{\mathrm{V}}$ are the effective density of states of electrons in conduction band and the effective density of states of holes in valence band, respectively. $N_{\mathrm{a}}$ is the acceptor concentration, $n_{\mathrm{i}}$ is the intrinsic carrier concentration and $W_{\mathrm{D}}$ is the depletion width in $\mathrm{MAPbI}_{3}$.

The simulation results are exhibited in Fig. 8c. As the acceptor concentration of tin-doped PQDs increased, both $V_{\mathrm{D} \_\mathrm{MAPbI} 3}$ and $W_{\mathrm{D}}$ showed downward trends, indicating that the hole transfer process in the $\mathrm{MAPbI}_{3}$ film was gradually facilitated. Besides, less electrons would be drifted to the interface between $\mathrm{MAPbI}_{3}$ and the PQD layer to recombine with holes. On the contrary, the direct contact between $\mathrm{MAPbI}_{3}$ and the carbon electrode would generate a large Schottky barrier in $\mathrm{MAPbI}_{3}$, resulting in higher values of $V_{\mathrm{D}_{-} \mathrm{MAPbI3}}$ and $W_{\mathrm{D}}$, shown in Fig. 8d. In one word, $\mathrm{MAPbI}_{3}$ films modified by tin-doped PQDs with higher acceptor concentrations would be provided with much enhanced hole transport performance. This simulation result explained 
1 why the photovoltaic performance of the $\mathrm{CsSn}_{0.2} \mathrm{~Pb}_{0.8} \mathrm{I}_{3}$ QDs-added PSC was better than the 2 pristine and the $\mathrm{CsSn}_{0.1} \mathrm{~Pb}_{0.9} \mathrm{I}_{3}$ QDs-added device.

a
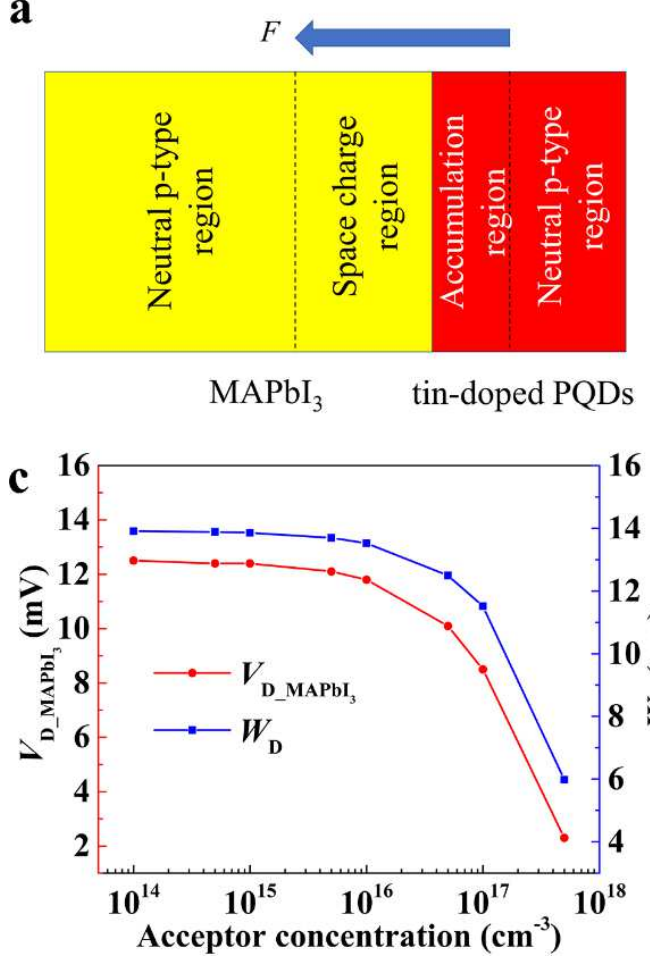

b

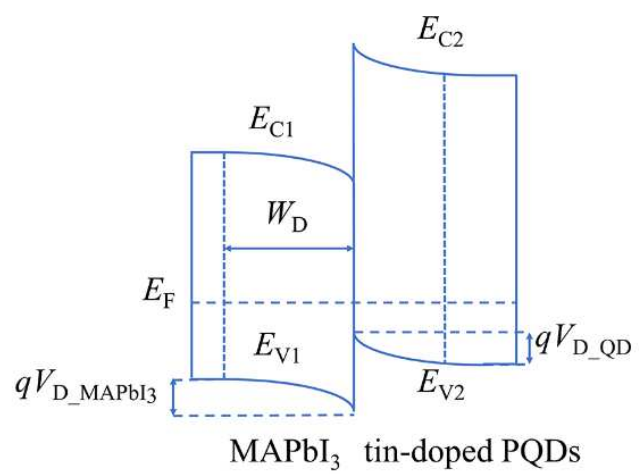

$\mathrm{MAPbI}_{3}$ tin-doped PQDs

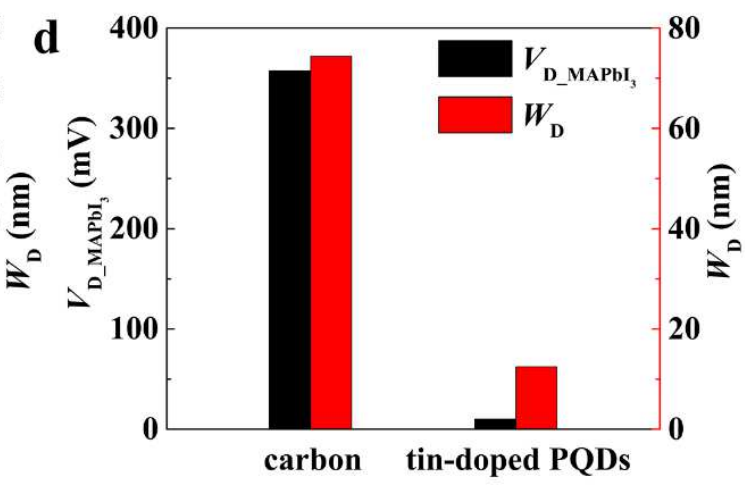

Fig. 8 a The one-dimensional $\mathrm{MAPbI}_{3} / \mathrm{PQDs}$ heterojunction model. b Corresponding energyband diagram under the equilibrium condition. $\mathbf{c}$ and $\mathbf{d}$ Simulation results for $\mathrm{MAPbI}_{3} / \mathrm{PQDs}$ and $\mathrm{MAPbI}_{3} /$ carbon heterojunctions.

\section{Conclusions}

In summary, tin-doped PQDs were added between $\mathrm{MAPbI}_{3}$ and the carbon electrode for enhanced PSC performance, due to their flexible energy levels and self-p-type doping effects.

Especially, with the incorporation of $\mathrm{CsSn}_{0.2} \mathrm{~Pb}_{0.8} \mathrm{I}_{3}$ QDs, the PCE value could be improved from $12.80 \%$ to $14.22 \%$, in comparison to the pristine device. It was attributed to the band

3 alignment and the appropriate $\mathrm{Sn}^{2+}$ doping content of the PQDs facilitating the hole extraction.

4 This work is prospected to provide a direction for the interface optimization of carbon-based 
PSCs based on PQDs.

3 Abbreviations

4 PSCs: perovskite solar cells; PQDs: perovskite quantum dots; HTLs: hole-transporting layers;

5 PCE: power conversion efficiency; ODE: 1-octadecene; OA: oleic acid; OAM: oleylamine

6 MeOAc: methyl acetate; TOP: trioctylphosphine; MAI: methylammonium; DMSO:

7 dimethylsulfoxide; DMF: N,N-dimethylformamide; FTO: fluorine-doped $\mathrm{SnO}_{2} ; \mathrm{c}-\mathrm{TiO}_{2}$ :

8 compact $\mathrm{TiO}_{2} ;$ m- $-\mathrm{TiO}_{2}$ : mesoporous $\mathrm{TiO}_{2}$; TEM: transmission electron microscope; SAED:

9 selected area electron diffraction; EDS: energy dispersive X-ray spectroscopy; VB: valence

10 band; PL: photoluminescence; IPCE: incident photon-to-electron conversion; EIS:

11 electrochemical impedance spectroscopy; XRD: X-ray diffraction.

13 Authors' contributions

14 CZ performed the experiments and drafted the manuscript with the help of ZYH, XHL, RWM. MWC, HFL and YPY helped to revised the manuscript. All authors read and approved the final manuscript.

\section{Funding}

This work was supported by the National Natural Science Foundation of China (NSFC)

Grant WUT (2020IB022). 


\section{Availability of data and materials}

2 The datasets used and/or analyzed during the current study are available from the corresponding

3 author on reasonable request.

\section{Competing interests}

6 The authors declare that they have no competing interests.

\section{Acknowledgements}

$9 \quad$ Not applicable

\section{References}

1. Rong YG, Hu Y, Mei AY, Tan HR, Saidaminov MI, Seok SI, McGehee MD, Sargent EH, Han HW. Challenges for commercializing perovskite solar cells. Science. 2018;361:eaat8235.

2. Liao JF, Wu WQ, Jiang Y, Zhong JX, Wang LZ, Kuang DB. Understanding of carrier dynamics, heterojunction merits and device physics: towards designing efficient carrier transport layer-free perovskite solar cells. Chem Soc Rev. 2020;49:354-381.

3. Huang JS, Yuan YB, Shao YC, Yan YF. Understanding the physical properties of hybrid perovskites for photovoltaic applications. Nat Rev Mater. 2017;2:17042. correlations to perovskite solar cell performance via compositional and thermal annealing controls. ACS Appl Mater Interfaces. 2019;11:6907-6917. 

and organic-inorganic halide perovskites for hybrid solar cells. Coord Chem Rev.

$2 \quad 2018 ; 374: 279-313$.

6. Eperon GE, Habisreutinger SN, Leijtens T, Bruijnaers BJ, Van Franeker JJ, DeQuilettes DW, Pathak S, Sutton RJ, Grancini G, Ginger DS, Janssen RAJ, Petrozza A, Snaith HJ. The importance of moisture in hybrid lead halide perovskite thin film fabrication. ACS Nano. 2015;9:9380-9393.

7. Meng FN, Liu AM, Gao LG, Cao JM, Yan YL, Wang N, Fan MQ, Wei GY, Ma TL. Current progress in interfacial engineering of carbon-based perovskite solar cells. J Mater Chem A. $2019 ; 7: 8690-8699$.

8. Chen K, Wu P, Yang WQ, Su R, Luo DY, Yang XY, Tu YG, Zhu R, Gong QH. Lowdimensional perovskite interlayer for highly efficient lead-free formamidinium tin iodide perovskite solar cells. Nano Energy. 2018;49:411-418.

9. Akin S, Altintas Y, Mutlugun E, Sonmezoglu S. Cesium-lead based inorganic perovskite quantum-dots as interfacial layer for highly stable perovskite solar cells with exceeding $21 \%$ efficiency. Nano Energy. 2019;60:557-566.

10. Zheng XP, Troughton J, Gasparini N, Lin YB, Wei MY, Hou Y, Liu JK, Song KP, Chen ZL, Yang C, Turedi B, Alsalloum AY, Pan J, Chen J, Zhumekenov AA, Anthopoulos TD, Han Y, Baran D, Mohammed OF, Sargent EH, Bakr OM. Quantum dots supply bulk- and surface-passivation agents for efficient and stable perovskite solar cells. Joule. 2019;3: 1963-1976.

11. Chen LC, Tien CH, Tseng ZL, Ruan JH. Enhanced efficiency of $\mathrm{MAPbI}_{3}$ perovskite solar cells with $\mathrm{FAPbX}_{3}$ perovskite quantum dots. Nanomaterials. 2019;9:121. 
12. Gao YB, Wu YJ, Lu HB, Chen C, Liu Y, Bai X, Yang LL, Yu WW, Dai QL, Zhang Y.

$\mathrm{CsPbBr} 3$ perovskite nanoparticles as additive for environmentally stable perovskite solar cells with 20.46\% efficiency. Nano Energy. 2019;59:517-526.

13. Cha MY, Da PM, Wang J, Wang WY, Chen ZH, Xiu FX, Zheng GF, Wang ZS. Enhancing perovskite solar cell performance by interface engineering using $\mathrm{CH}_{3} \mathrm{NH}_{3} \mathrm{PbBr}_{0.9} \mathrm{I}_{2.1}$ quantum dots. J Am Chem Soc. 2016;138:8581-8587.

14. Sidhik S, Esparza D, Martínez-Benítez A, Lopez-Luke T, Carriles R, Mora-Sero I, de la Rosa E. Enhanced photovoltaic performance of mesoscopic perovskite solar cells by controlling the interaction between $\mathrm{CH}_{3} \mathrm{NH}_{3} \mathrm{PbI}_{3}$ films and $\mathrm{CsPbX}$ perovskite nanoparticles. J Phys Chem C. 2017;121:4239-4245.

15. Li B, Zhang YN, Zhang YL, Yin LW. Graded heterojunction engineering for holeconductor-free perovskite solar cells with high hole extraction efficiency and conductivity. Adv Mater. 2017;29:1701221.

16. Chan CY, Wang YY, Wu GW, Diau EWG. Solvent-extraction crystal growth for highly efficient carbon-based mesoscopic perovskite solar cells free of hole conductors. J Mater Chem A. 2016;4:3872-3878.

17. Sheng YS, Mei AY, Liu SA, Duan M, Jiang P, Tian CB, Xiong YL, Rong YG, Han HW, Hu Y. Mixed (5-AVA) $)_{x} \mathrm{MA}_{1-x} \mathrm{PbI}_{3-y}(\mathrm{BF} 4)_{y}$ perovskites enhance the photovoltaic performance of hole- conductor-free printable mesoscopic solar cells. J Mater Chem A. 2018;6:23602364.

18. Xiong YL, Liu Y, Lan K, Mei AY, Sheng YS, Zhao DY, Han HW. Fully printable holeconductor-free mesoscopic perovskite solar cells based on mesoporous anatase single 
crystals. New J Chem. 2018;42:2669-2674.

19. Van der Stam W, Geuchies JJ, Altantzis T, Van den Bos KHW, Meeldijk JD, Van Aert S, Bals S, Vanmaekelbergh D, De Mello Donega C. Highly emissive divalent-ion-doped colloidal $\mathrm{CsPb}_{1-x} \mathrm{M}_{x} \mathrm{Br}_{3}$ perovskite nanocrystals through cation exchange. J Am Chem Soc. 2017;139:4087-4097.

20. Zhang JB, Zhang LW, Cai P, Xue XG, Wang MK, Zhang J, Tu GL. Enhancing stability of red perovskite nanocrystals through copper substitution for efficient light-emitting diodes. Nano Energy. 2019;62:434-441.

21. Vitoreti ABF, Agouram S, de la Fuente MS, Muñoz-Sanjose V, Schiavon MA, Mora-Sero I. Study of the partial substitution of $\mathrm{Pb}$ by $\mathrm{Sn}$ in $\mathrm{Cs}-\mathrm{Pb}-\mathrm{Sn}-\mathrm{Br}$ nanocrystals owing to obtaining stable nanoparticles with excellent optical properties. J Phys Chem C. 2018;122:1422214231.

22. Gupta $\mathrm{S}$, Cahen D, Hodes G. How $\mathrm{SnF}_{2}$ impacts the material properties of lead-free tin perovskites. J Phys Chem C. 2018;122:13926-13936.

23. Mosconi E, Umari P, De Angelis F. Electronic and optical properties of mixed Sn-Pb organohalide perovskites: a first principles investigation. J Mater Chem A. 2015;3:92089215.

24. Chung I, Song JH, Im J, Androulakis J, Malliakas CD, Li H, Freeman AJ, Kenney JT, Kanatzidis MG. CsSnI 3 : Semiconductor or metal? High electrical conductivity and strong near-infrared photoluminescence from a single material. High hole mobility and phasetransitions. J Am Chem Soc. 2012;134:8579-8587.

25 Liu F, Ding C, Zhang YH, Ripolles TS, Kamisaka T, Toyoda T, Hayase S, Minemoto T, 
Yoshino K, Dai SY, Yanagida M, Noguchi H, Shen Q. Colloidal synthesis of air-stable alloyed $\mathrm{CsSn}_{1-\mathrm{x}} \mathrm{Pb}_{\mathrm{x}} \mathrm{I}_{3}$ perovskite nanocrystals for use in solar cells. J Am Chem Soc. 2017; 139:16708-16719.

26. Xu HZ, Duan JL, Zhao YY, Jiao ZB, He BL, Tang QW. 9.13\%-efficiency and stable inorganic $\mathrm{CsPbBr}_{3}$ solar cells. Lead-free $\mathrm{CsSnBr}_{3-x} \mathrm{I}_{x}$ quantum dots promote charge extraction. J Power Sources. 2018;399:76-82.

27. Duan QQ, Ji JY, Hong X, Fu YC, Wang CY, Zhou K, Liu XQ, Yang H, Wang ZY. Design of hole-transport-material free $\mathrm{CH}_{3} \mathrm{NH}_{3} \mathrm{PbI}_{3} / \mathrm{CsSnI}_{3}$ all-perovskite heterojunction efficient solar cells by device simulation. Solar Energy. 2020;201:555-560.

28. Zhang XL, Cao WY, Wang WG, Xu B, Liu S, Dai HT, Chen SM, Wang K, Sun XW. Efficient light-emitting diodes based on green perovskite nanocrystals with mixed-metal cations. Nano Energy. 2016;30:511-516.

29. Swarnkar A, Marshall AR, Sanehira EM, Chernomordik BD, Moore DT, Christians JA, Chakrabarti T, Luther JM. Quantum dot-induced phase stabilization of a-CsPbI 3 perovskite for high-efficiency photovoltaics. Science. 2016;354:92-95.

30. Minemoto T, Murata M. Impact of work function of back contact of perovskite solar cells without hole transport material analyzed by device simulation. Curr Appl Phys. 2014;14: 1428-1433.

31. Tian CB, Mei AY, Zhang SJ, Tian HR, Liu S, Qin F, Xiong YL, Rong YG, Hu Y, Zhou YH, Xie SY, Han HW. Oxygen management in carbon electrode for high-performance printable perovskite solar cells. Nano Energy. 2018;53:160-167.

32. Jeon NJ, Na H, Jung EH, Yang TL, Lee YG, Kim G, Shin HW, Seok SI, Lee J, Seo J. A 
fluorene-terminated hole-transporting material for highly efficient and stable perovskite solar cells. Nat Energy. 2018;3:682-689.

33. Li C, Wang FZ, Xu J, Yao JX, Zhang B, Zhang CF, Xiao M, Dai SY, Li YF, Tan ZA. Efficient perovskite/fullerene planar heterojunction solar cells with enhanced charge extraction and suppressed charge recombination. Nanoscale. 2015;7:9771-9778.

34. Song JX, Bian J, Zheng EQ, Wang XF, Tian WJ, Miyasaka T. Efficient and environmentally stable perovskite solar cells based on $\mathrm{ZnO}$ electron collection layer. Chem Lett. 2015;44: 610-612.

35. Sanehira EM, Marshall AR, Christians JA, Harvey SP, Ciesielski PN, Wheeler LM, Schulz P, Lin LY, Beard MC, Luther JM. Enhanced mobility $\mathrm{CsPbI}_{3}$ quantum dot arrays for recordefficiency, high-voltage photovoltaic cells. Sci Adv. 2017;3:eaao4204.

36. Akkerman QA, Park S, Radicchi E, Nunzi F, Mosconi E, De Angelis F, Brescia R, Rastogi P, Prato M, Manna L. Nearly monodisperse insulator $\mathrm{Cs}_{4} \mathrm{PbX}_{6}(\mathrm{X}=\mathrm{Cl}, \mathrm{Br}$, I) nanocrystals, their mixed halide compositions, and their transformation into $\mathrm{CsPbX}_{3}$ nanocrystals. Nano Lett. 2017; 17:1924-1930.

37. De Weerd C, Lin JH, Gomez L, Fujiwara Y, Suenaga K, Gregorkiewicz T. Hybridization of single nanocrystals of $\mathrm{Cs}_{4} \mathrm{PbBr}_{6}$ and $\mathrm{CsPbBr}_{3}$. J Phys Chem C. 2017;121:19490-19496.

38. Laban WA, Etgar L, Depleted hole conductor-free lead halide iodide heterojunction solar cells. Energy Environ Sci. 2013;6:3249-3253.

39. Kumar RC. On the solution of poisson equation for an isotype heterojunction under zerocurrent condition. Solid State Electron. 1968;11:543-551. 
Figures
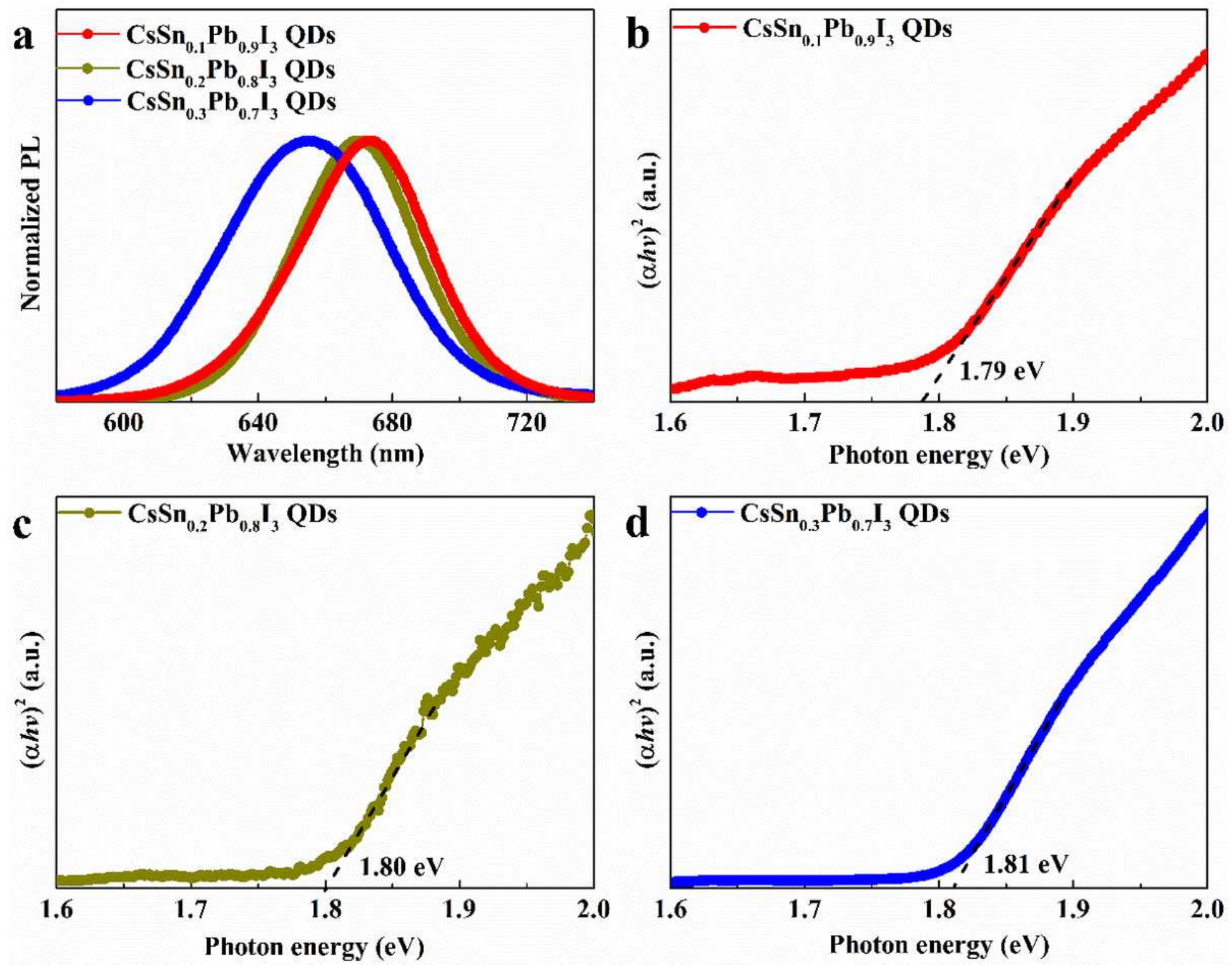

Figure 1

a Normalized PL spectra and b-d Tauc plots of different tin-doped PQDs 
a

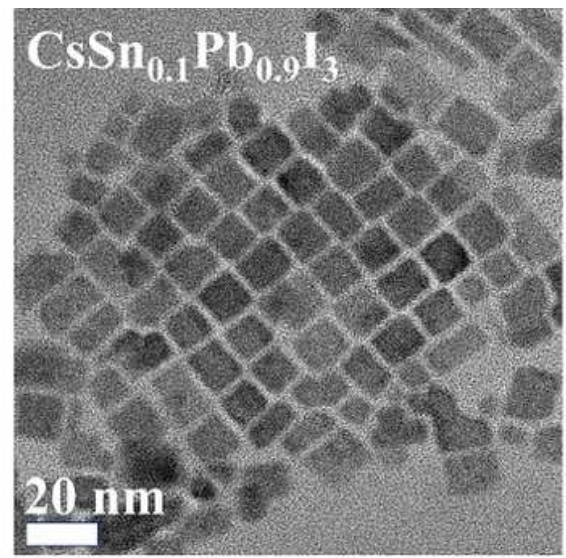

d

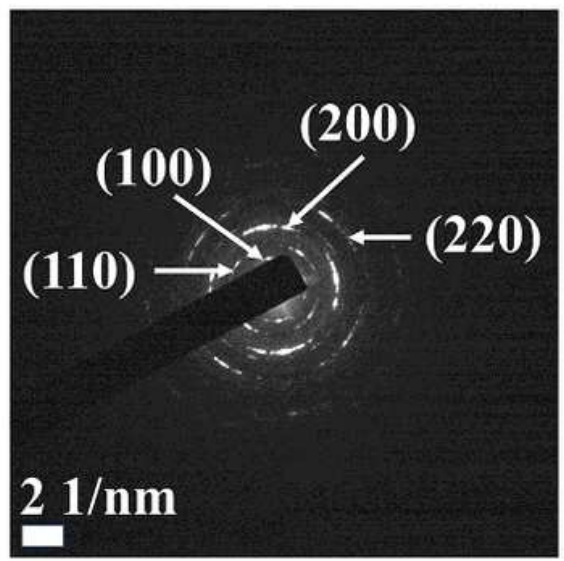

g

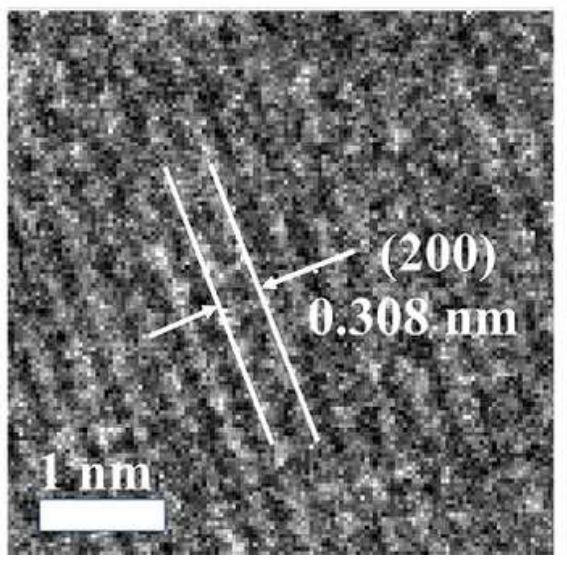

b

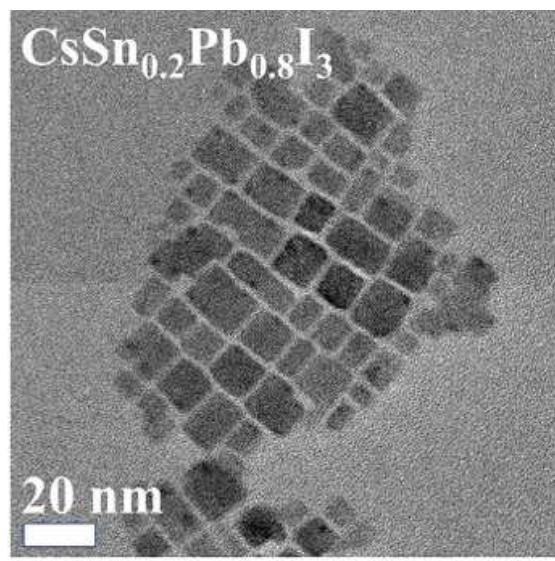

e

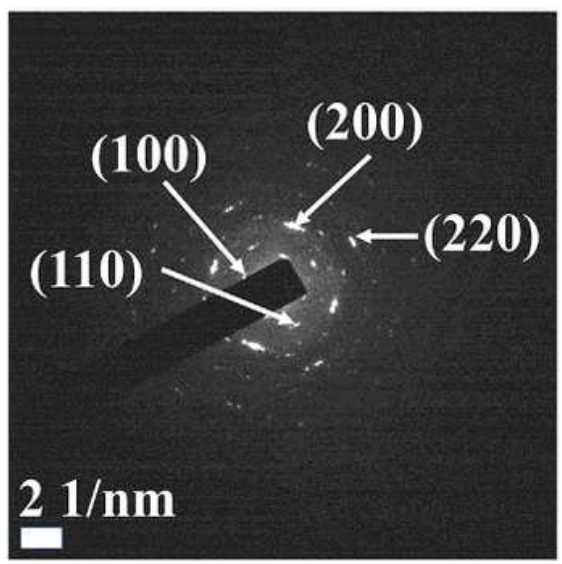

h

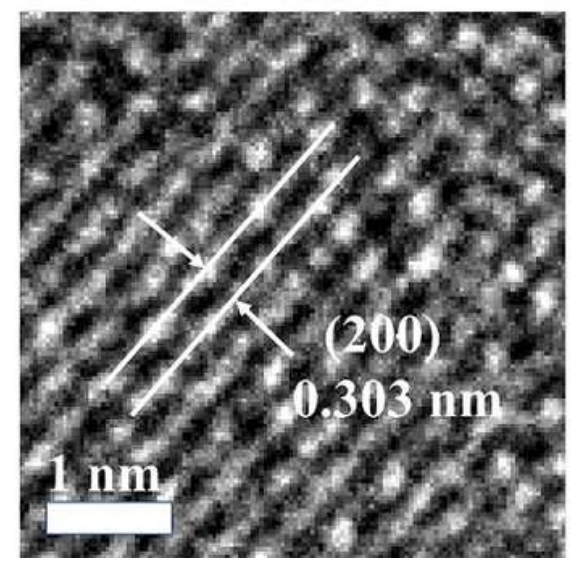

c $\operatorname{CsSn}_{0.3} \mathrm{~Pb}_{0.7} \mathrm{I}_{3}$

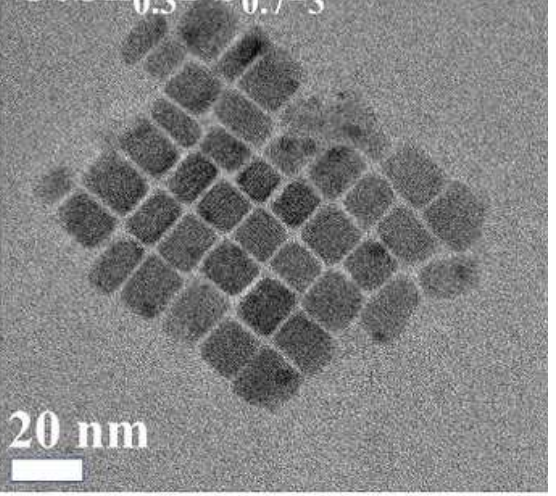

f

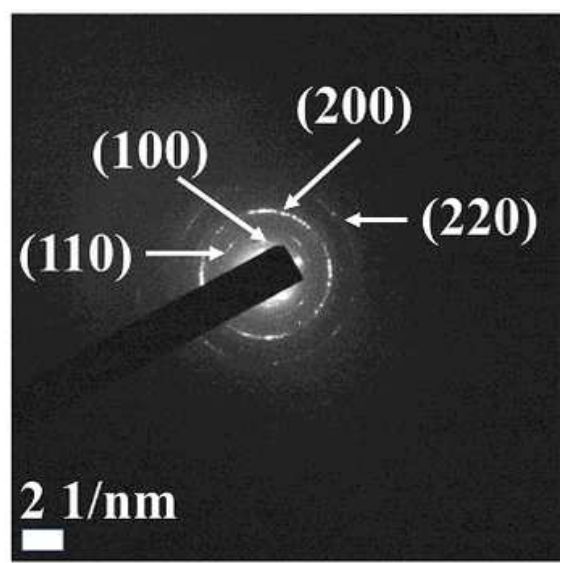

i

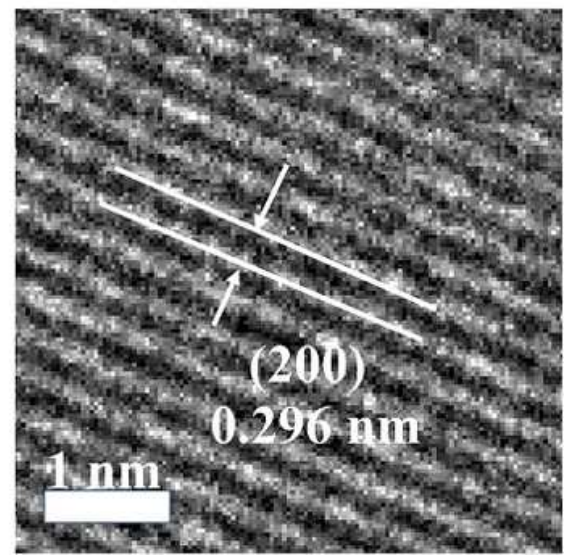

Figure 2

a-c TEM images, d-f SAED patterns and g-i enlarged TEM images of CsSn0.1Pb0.9/3 QDs, CsSn0.2Pb0.8I3 QDs and CsSn0.3Pb0.7I3 QDs. 


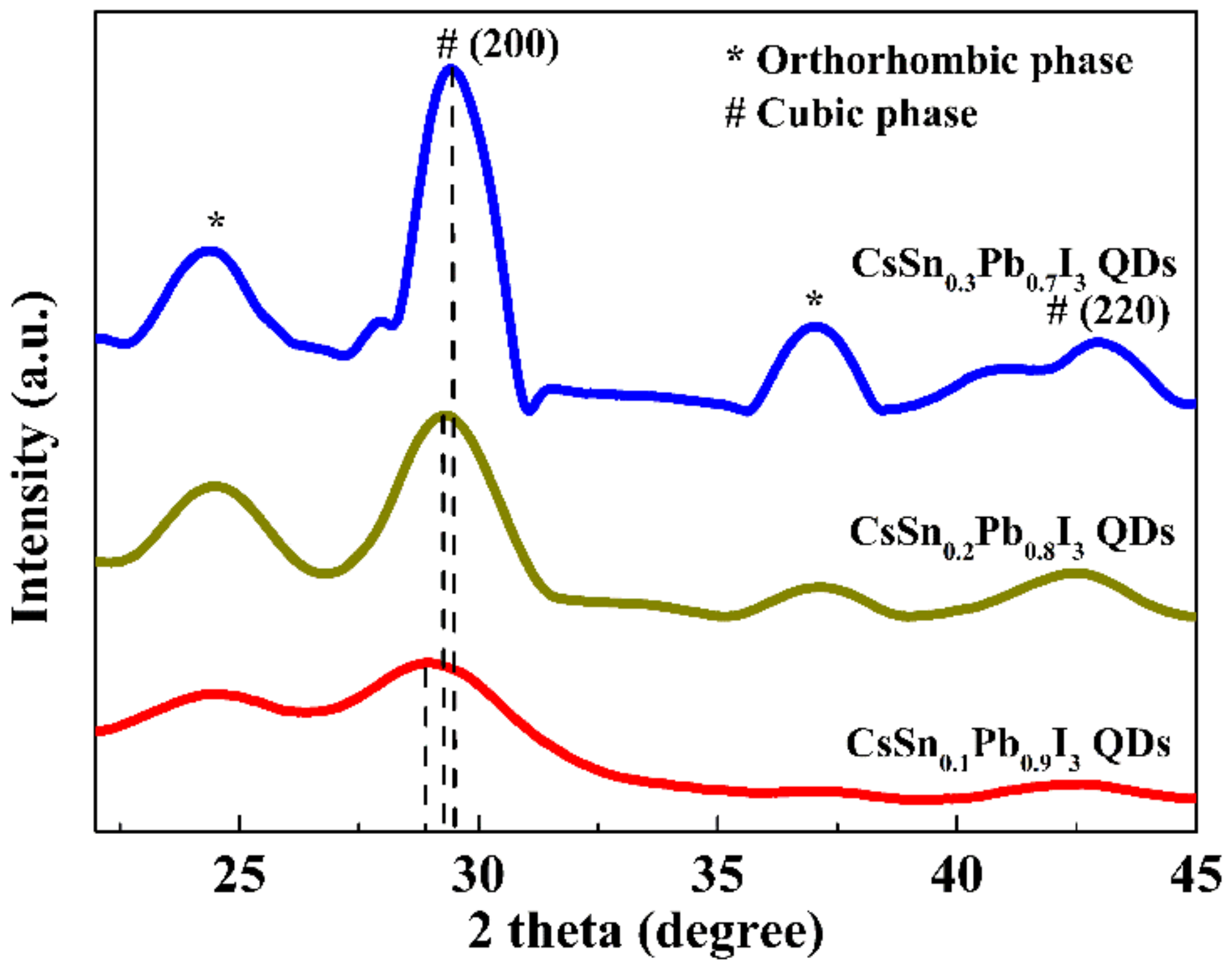

Figure 3

XRD patterns of different tin-doped PQDs 
Energy (eV)

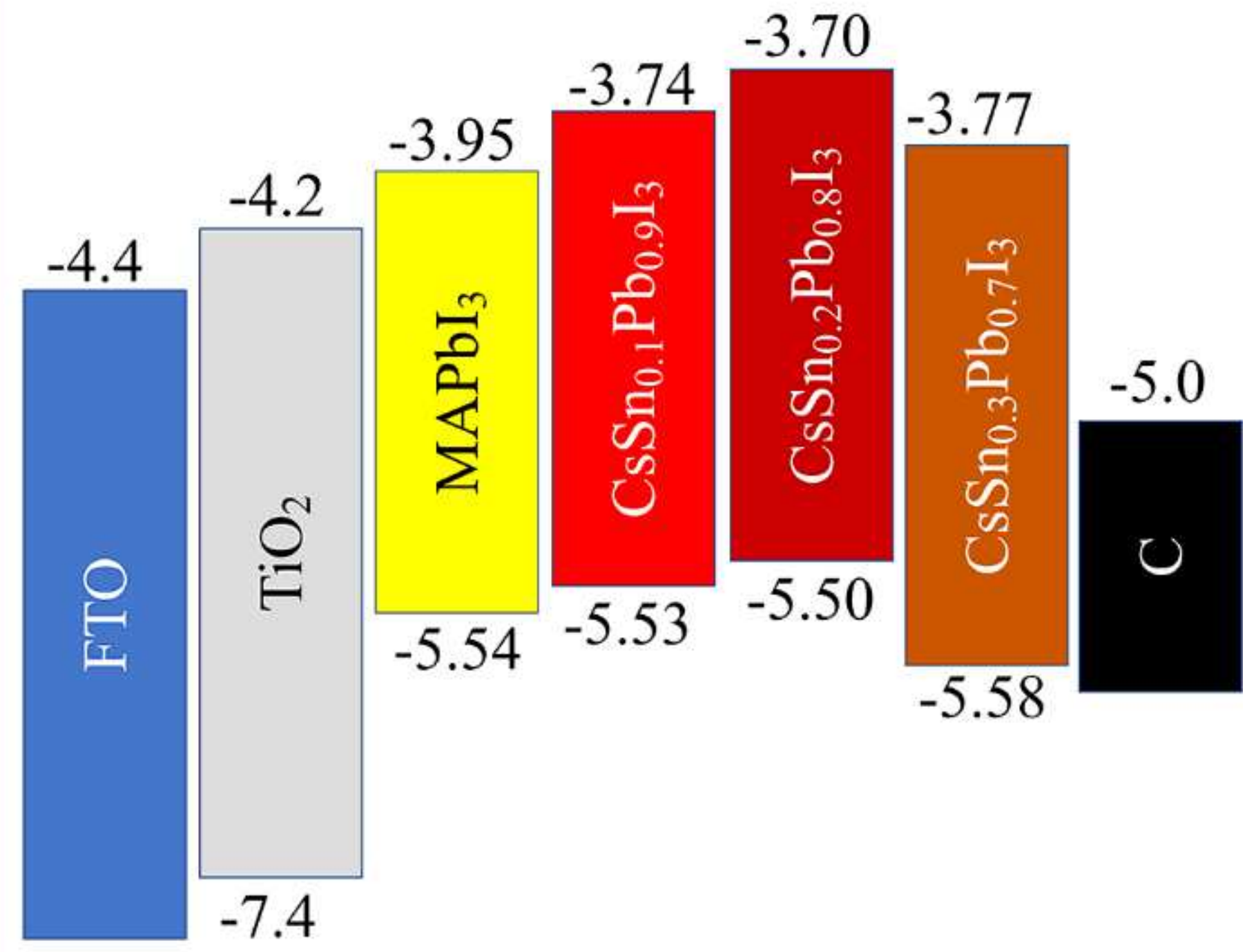

Figure 4

Band structures of different materials in PSCs 
a

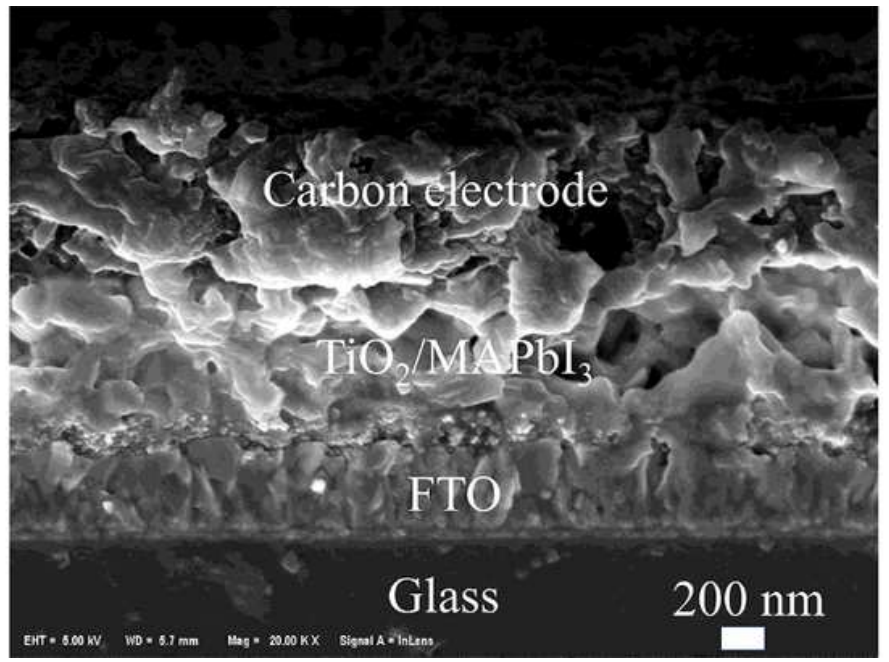

b

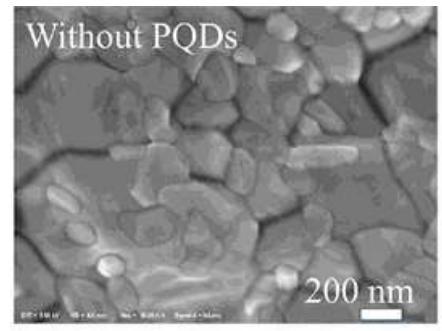

d

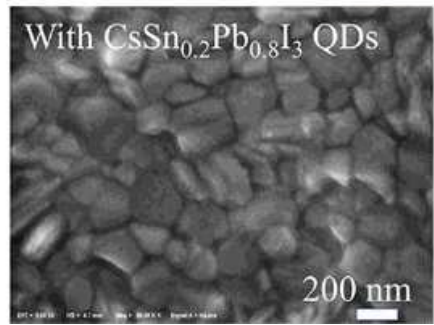

c

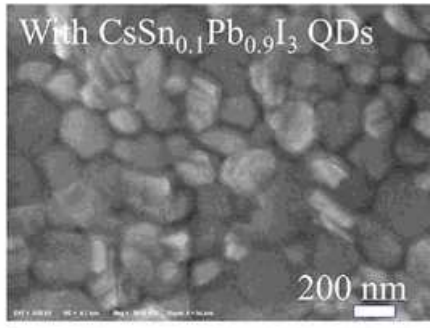

f

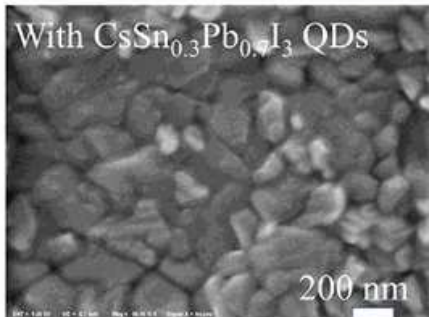

Figure 5

a Cross-sectional image of the PSC. b-f Perovskite films without and with tin-doped PQDs.

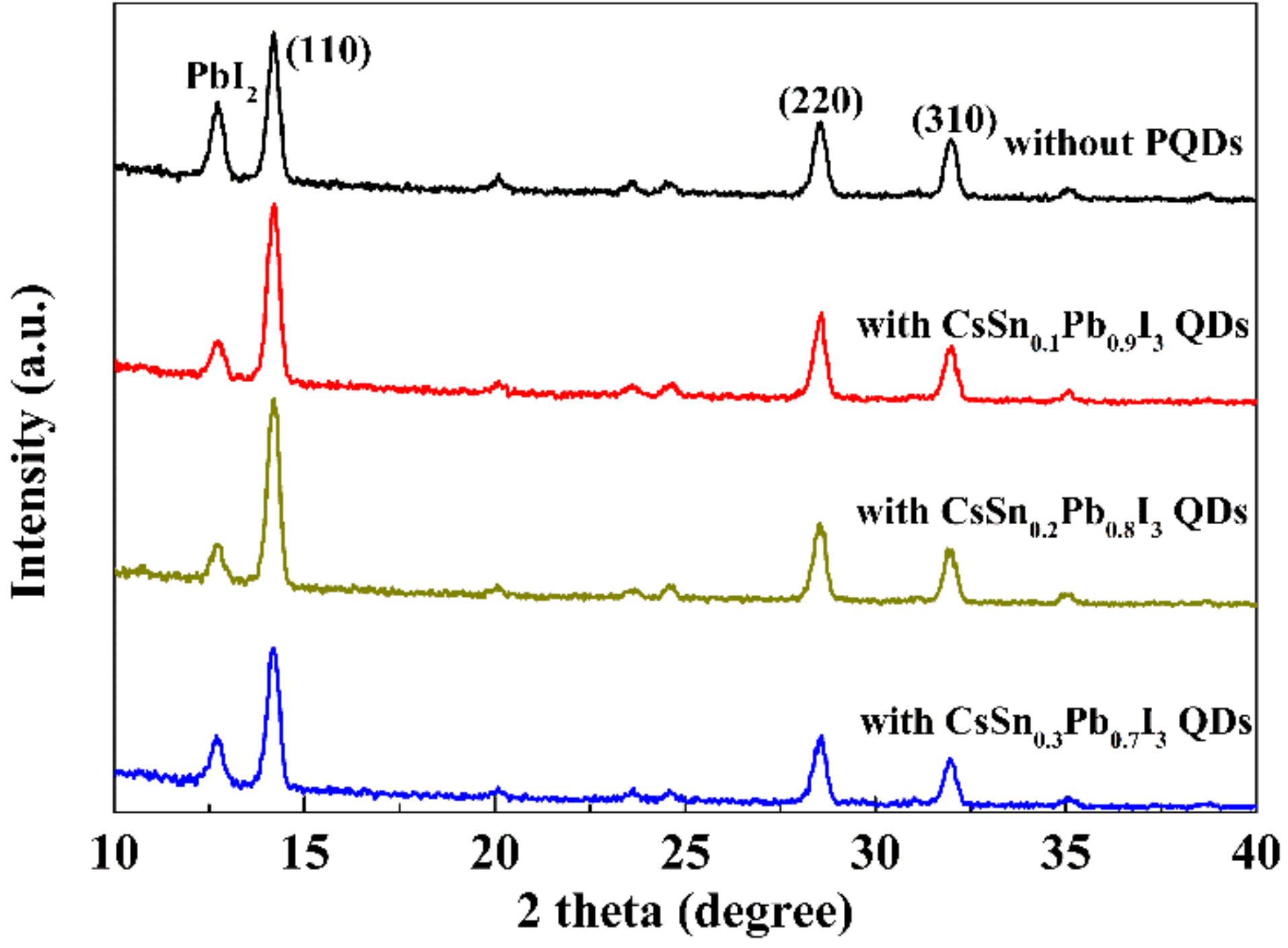

Figure 6 

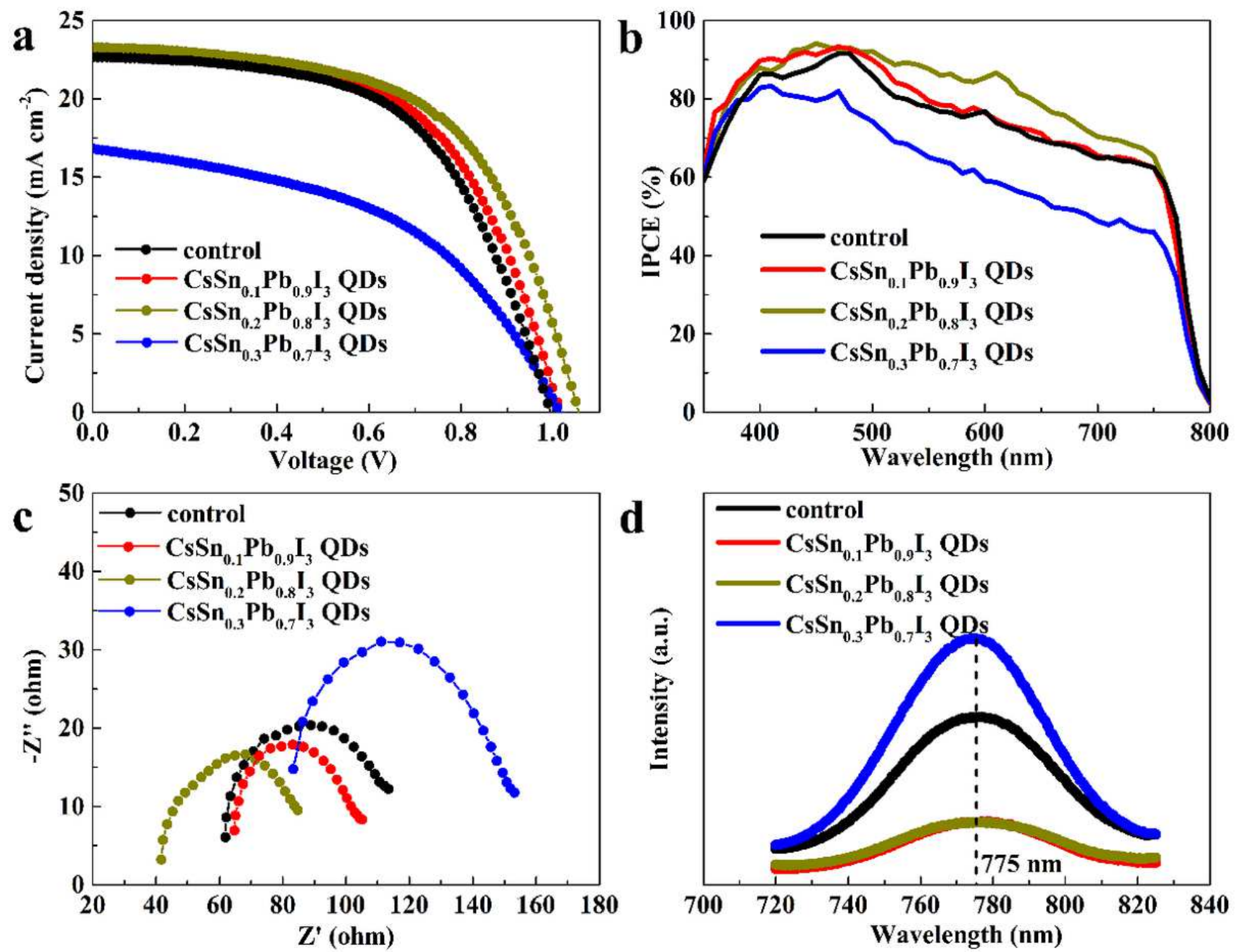

Figure 7

a J-V curves, b IPCE spectra and c EIS measurements of different PSCs. d PL spectra of perovskite films with and without tin-doped PQDs. 
a

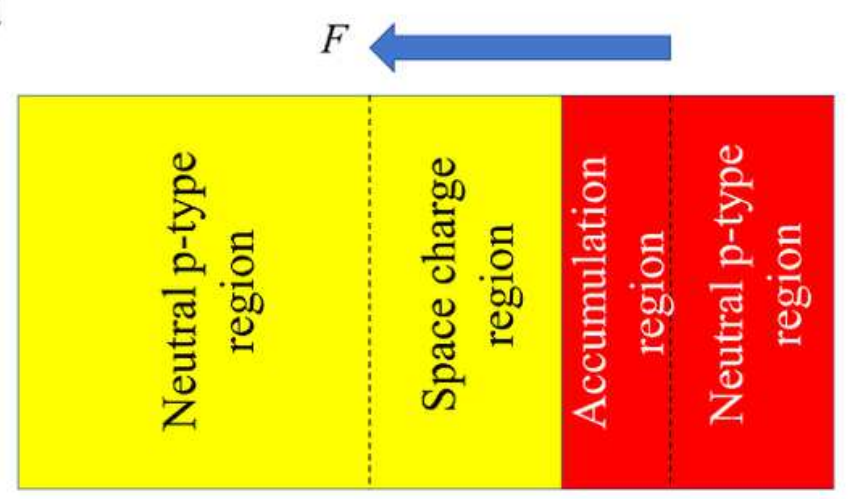

$\mathrm{MAPbI}_{3}$

b

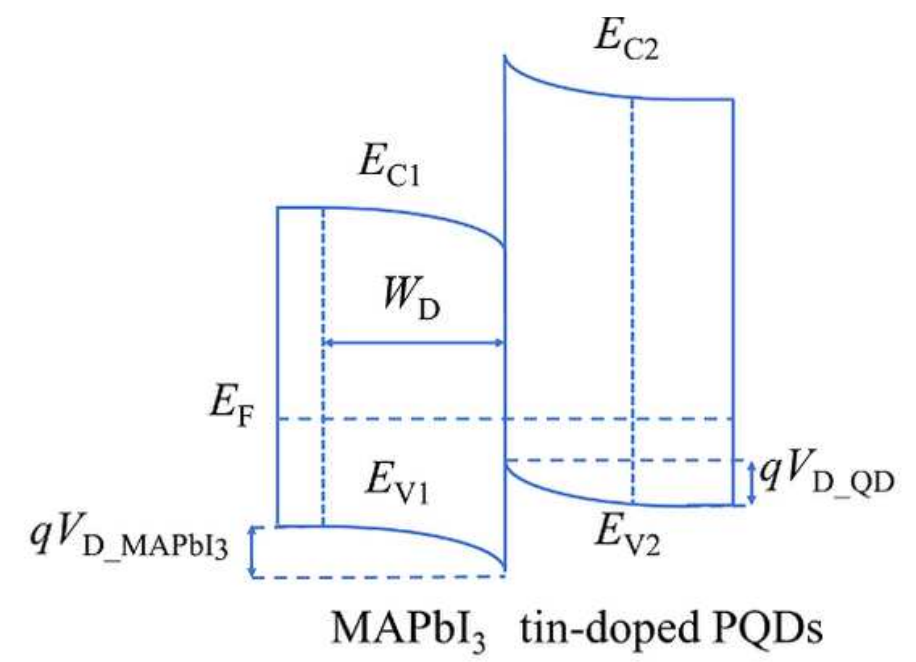

c
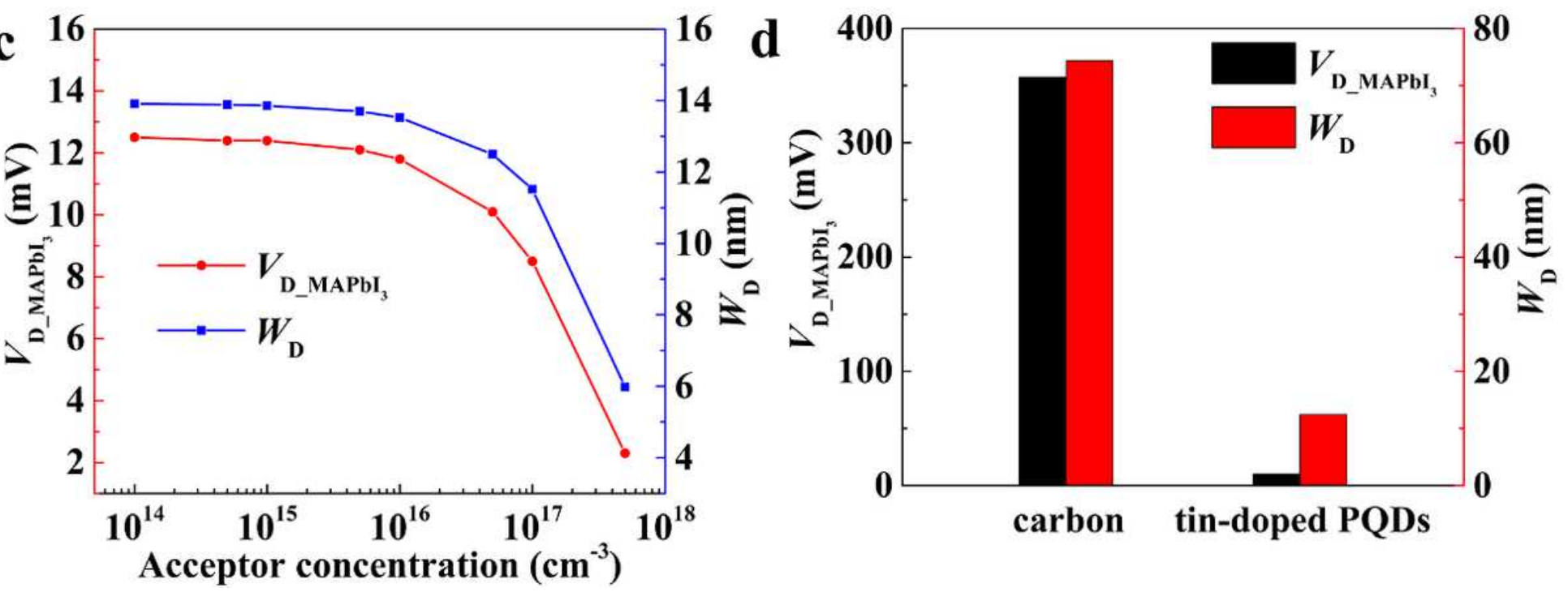

Figure 8

a The one-dimensional MAPbI3/PQDs heterojunction model. b Corresponding energy-band diagram under the equilibrium condition. $c$ and $d$ Simulation results for MAPbI3/PQDs and MAPbI3/carbon heterojunctions.

\section{Supplementary Files}

This is a list of supplementary files associated with this preprint. Click to download.

- NRLsupplementarymaterial.docx 